\title{
From Contrapuntal Music to Polyphonic Novel: Aldous Huxley's Point Counter Point
}

\author{
Mevlüde ZENGIN* \\ Cumhuriyet Üniversitesi
}

\begin{abstract}
Özet
İngiliz yazar Aldous Huxley'nin Ses Sese Karşı (1928) adlı romanı ilk bakışta birçok değişik kişinin öykülerini ve onların içinde yaşadıkları modern dünyaya ve sürdürdükleri yaşamlara ilişkin bakış açılarını içeren bir roman görünümündedir. İşte, romanın tam da bu özelliği onun polifonik bir roman olarak çalışılmasını sağlamaktadır. Roman okura birbirinden oldukça farkı bir grup karakter ile çağdaş toplumdan geniş bir yelpaze sunmaktadır. Roman kişileri kolaylıkla fark edilebilecek fiziksel, zihinsel, duygusal, psikolojik ve ahlâki özellikleriyle karakterize edilmiş ve bireyselleştirilmiştir. Her biri sosyal statü, politik görüş, zenginlik vb. farklılıklarla donatılmışlardır. Bu yüzden de Ses Sese Karş/da polifonik yapıyı sağlayan birbirinden çok farklı bakış açıları, daima çatışan sesler, çelişen kanı ve düşünceler eşzamanlı olarak duyulmaktadır. Çokseslilik müziksel bir terim olup birden fazla notanın ve ezginin bir ritm oluşturmak üzere aynı anda çalınmasıdır. Romanda ise polifoni ilk kez M. M. Bakhtin tarafından Dostoyevski'nin eserlerini analiz etmek üzere kullanılmıştır. Bu çalışmada amaç öncelikle Bakhtin'de çokseslilik kavramı ile onunla yakından ilişkili diyalojizm ve çok dillilik (heteroglossia) kavramlarını açıklamak, daha sonra ise polifonik ve diyalojik bir söylem olarak Ses Sese Karş/nın özelliklerini, romanın diyalojik düzlemini ve heteroglot özelliklerini irdeleyerek ortaya koymaktır.

Anahtar Kelimeler: Aldous Huxley, Ses Sese Karşı, kontrpuntal müzik, polifonik roman, söyleşimsel, söyleşimsellik, çok dillilik (çok söylemlilik), anlam çokluğu.
\end{abstract}

\begin{abstract}
Taken at face value Point Counter Point (1928) written by Aldous Huxley seems to be a novel including many stories of various and sundry people and reflecting their points of view about the world in which they live and about the life they have been leading. However, it is this very quality of the novel that provides grounds for the study of the novel as a polyphonic one. The novel presents to its reader an aggregate of strikingly different characters and thus a broad spectrum of contemporary society. The characters in the novel are all characterized by and individualized with easily recognizable physical, intellectual, emotional, psychological and moral qualities. Each of them is well-contrived
\end{abstract}

*Yrd. Doç. Dr., Cumhuriyet Üniversitesi, Edebiyat Fakültesi, İngiliz Dili ve Edebiyatı Bölümü, mevludezengin@yahoo.com 
through their differences in social status, political views, wealth, etc. Thus, many different viewpoints, conflicting voices, contrasting insights and ideas are heard and seen synchronically in Point Counter Point, which makes it polyphonic. Polyphony is a musical motif referring to different notes and chords played at the same time to create a rhythm. It was first adopted by M. M. Bakhtin to analyze F. M. Dostoyevsky's fiction. The aim of this study is firstly to elucidate, in Bakhtinian thought, polyphony and then dialogism and heteroglossia closely related to his concept of polyphony; and then to put the polyphonic qualities in Point Counter Point forth, studying the novel's dialogism and heteroglot qualities.

Keywords: Aldous Huxley, Point Counter Point, contrapuntal music, polyphonic novel, dialogic, dialogism heteroglossia, multiplicity of meaning

\section{Giriş}

İngiliz yazar Aldous Huxley'nin Ses Sese Karşı (Point Counter Point) (1928) adlı romanı, yazarın hepsine de aynı uzaklıkta olduğu bir dizi karakter aracılığıyla okura daha çok modern dünyaya ilişkin değişik kanı ve yaşam görüşleri sunan bir düşünce romanıdır. Eser geleneksel romanların çizgisi dışına çıkarak bir dizi modernist teknik içermekte, geleneksel gerçekçi romanda olduğu gibi bir ana karakter üzerine kurulu bir öykü değil, birbirleriyle arkadaş, akraba veya sevgili olma durumu ile ilişkili tam olarak on dokuz roman kişisi üzerine kurulmuş öykülerden oluşmaktadır. Romanda yansıtılan toplum, dekadan bir toplum olup, aristokrat ailelerden gelen ve hiç çalışmadan yaşamını sürdüren zenginlerle, bilim adamları, entelektüeller ile yazar ve sanatçıların ya da kendini öyle sananların çoğunlukta olduğu aslında yozlaşmış bir toplumdur. Ses Sese Karş/daki roman kişilerini iki gruba ayırmak yanlış olmayacaktır. Birinci gruptakiler tümünün romanda ana karakter sayılabileceği ve tek tek öykülerini okuduğumuz, seslerini duyduğumuz on dokuz kişilik bir grup, diğer grup ise tek tek öyküleri verilmeyen, birinci gruptaki kişilerin yaşamlarında bir şekilde var olan ve romanda birinci gruptakilere oranla çok daha az yansıtılan ikincil derecede önemli olan karakterler. Birinci gruptaki roman kişilerinden hiçbiri ön plana çıkmayıp, yazarın ve anlatııının gözünde hepsi de hemen hemen aynı önemi taşımaktadır. Ayrıca roman karakterlerinin sesleri de anlatıının sesi kadar önemli varsayılmış ve onların, yazarın ya da anlatıının ideolojisinden ve sesinden farklı ideolojiler doğrultusunda konuşmalarına ve böylece seslerini duyurmalarına izin verilmiştir. Huxley romanında aynı çok sesli müzikte olduğu gibi değişik sesleri bir araya getirmiş ve insanların değişik kanı, görüş, anlayış ve özelliklerinin bazen de çatışmasını vererek yaşamın kendisinin de böyle olduğu görüşünü yansıtmıştır. Huxley polifonik bir romanın önemli bir karakteristiğini romanına uygulamışır. Polifonik bir romanda önemli olan "kahramanın dünyaya nasıl göründüğü değil, öncelikle dünyanın kahramana nasıl göründüğü ve kahramanın kendi kendisine nasıl göründüğüdür" (Bakhtin, 2004: 97). Ses Sese Karşı bu yenilikçi özellikleriyle okurun dikkatini çeken polifonik bir yapı kazanmışıı. Polifonik yapısı sayesinde roman, modern toplumun içinde barındırdığı birçok farklı görüşü yansıtmaktadır; bu fikir ve anlayışlar çeşitliliğinden doğan kişilikleri ve egoları yansıtmakla kalmayıp, monolojik (teksesli) romanlarda doğal olarak tek bir bakış açısından verilen konulara çokseslilik getirmektedir. Ses Sese Karşının polifonik yapısı onun 
bir 'fikir romanı' olmasıyla da iç içe geçen bir özelliktir. Romanda birbiriyle çatışan bir dizi görüş vardır daha doğrusu bu görüşlerin kişileştirilmiş halleri sürekli farklı düşünceleri ile seslerini duyurmaktadırlar. Huxley, romanın polifonik yapısı sayesinde çalışmada daha sonra neler olduğuna değineceğimiz bir dizi konuyla birlikte cinsellik, aşk ve şehvet gibi konularla cinselliğin sado-mazoşizm gibi farklı eğilimlerine şöyle de olsa değinmektedir. Zannediyoruz ki Huxley'nin bu gibi konuları çoksesli bir roman kurgusu içinde ele almış olmasından dolayı roman hala okunmaya değer kalmıştır; çünkü bu konuları monolojik bir düzlemde ele almış olsaydı romanı erotik bir kitap gibi gözükebilirdi. Belli ki Huxley romanının bu çoksesli ortamında insana dair ne varsa bahsetmeden geçmek istememiştir. Roman bu haliyle yaşama özgü hangi kavram hangi olgu varsa hepsine de kucak açmıştır. Bu çalışmada Ses Sese Karş/nın polifonik yapısı irdelenecek, romanın çoksesliliğine giden yolda diyalojizmin işlevi araştırılacak, bu bağlamda romanın diyalojik söylemi ve heteroglot yapısı çalışılacak ve bu biçimsel özelliklerin romanın tematik özellikleriyle nasıl bağdaştığı araştırılacaktır.

Müzikte çokseslilik (kontrpuan) faklı tonlarda sesleri ve aslında birbirine benzemeyen değişik melodileri kulağa hoş gelecek bir ritim oluşturacak ve birbiriyle uyumlu olacak şekilde dizmektir. Bir ezgiye eşlik etmek üzere yaratılan ezgi ya da ezgiler de kontrpuan olarak adlandırılır. Romandaki çokseslilik (polyphony) ise genel anlamıyla değişik seslerin kontrpuntal tarzda yan yana konmalarıdır. Ancak Huxley romanına sadece "counterpoint" adını vermemiş, "point counter point" yani 'note counter note' veya 'note against note'(notaya karşı nota) gibi bir isim vererek romanın başlığıyla ilgili yapılabilecek yorumu biraz daha karmaşık hale getirmiştir. $\mathrm{O}$ halde burada ezgilerin çokluğu ve onun karşısında yine bir ezgiden söz etmek yanlış olmaz. Nasıl ki bir müzik parçasında farklı ezgiler bir bütün oluşturmak için bir arada bulunuyor ise Ses Sese Karş/da da aslında tek tek bakıldığında farklı olan ancak bir araya geldiğinde de birbiriyle kaynaşmayan, hâlâ bağımsızlığını koruyabilen veya çelişen çeşitli sesler ve görüşler bulunmaktadır. Bu anlamda romandaki çokseslilik ile bir fügdeki kontrpuntal seslerin bileşimi arasında bir benzerlik kurulabilmektedir. Eduard Hugo Strautch (2001) * Ses Sese

\footnotetext{
* Yabancı dildeki ikincil kaynaklardan alıntılanan bölümlerin İngilizceden Türkçeye çevirileri bu makalenin yazarı tarafından yapılmıştır.
}

Karş/da "her bir karakterin probleminin bir diğerininkine benzediğini" ve "tıpkı bir fügdeki ya da çok sesli müzikteki gibi farklı motiflerin kesiştiği, açımlandığı ve birbirini tamamladığını" (s. 57) belirtmektedir. Jerome Meckier (1969), Ses Sese Karş/nın çoksesli müzik ile ilişkisinden bahsederken "ileri düzeyde müzik bilgisine sahip bir eleştirmen, [romandaki] hızlı geçişleri, ruhsal durumlardaki değişimleri, kontrpuntal öyküleri, karakter ve durumları birkaç kat arttıran çeşitliliği hemen anlayabilir" (s. 129) der. Huxley 1926'da babasına yazdığı bir mektubunda henüz yazmamış olduğu romanının bir anlamda polifonik özelliğine değinerek "uzun ve karmaşık bir roman" üzerinde çalıştığını belirtmiş ve romanını "değişik 
özellikleriyle yaşamın bir resmi, farklı şeylerin eşzamanlı olarak resmedilmesi" (Smith, 1969, s. 276) şeklinde betimlemiştir. Farklı seslerin eşzamanlı olarak duyulması tam da polifonik bir romandan beklenen bir özelliktir. Kendisiyle yapılan bir röportajda ise Huxley, edebiyatta "en önemli şeyin öncelikle ifade edilemeyecek olanı ifade edebilme ve ikinci olarak da anlam çokluğunu ifade etmek" olduğunu belirtmiş, "herhangi iyi bir edebiyat eserinin kaçınılmaz olarak bu anlam çokluğunu ifade etmek zorunda" olduğunu vurgulamıştır (Aldous Huxley - The Herman Harvey Interview, 2013). Romanın II. Bölümü'nde ise Tantomount'ların evindeki partide çalan müzikten söz ederken çoksesli müziğin betimlemesini Huxley (yazar-anlatıcı) Johann Sebastian Bach'ın müziği aracilığılla, ve bir dizi ayrıntıyla birlikte çoksesli müziğin yaşamla olan ilişkisini de kurarak, bir anlamda Ses Sese Karş̧nın polifonik bir dünyası olacağını okura haber vermektedir:

Dünyada yüce şeyler vardır; gerçekten birer fatih olan, aslında yeryüzünün efendileri sayılabilecek insanlar vardır. Ama Bach, fugue'e [füg'e] benzeyen allegro bölümünde, bunların egemenliklerini sürdürdükleri dünyanın, karışık ve çok çeşitli olduğunu düşünmüştü. İnsan, gerçeği bulduğunu sanır; kemanlar, bu apaçık, kesin, karşı konulmaz gerçeği müjdeler; bu gerçek elinizdedir, zafer sevinci içinde avucunuzda tutarsınız onu. Ama bu gerçek elinizden kaçıp, önce viyolonseller, daha sonra da Pongileoni'nin titreyen hava sütunu sayesinde, yeni bir biçimde ortaya çıkar. Müziğin çeşitli parçaları ayrı ayrı yaşarlar; birbirlerine dokunurlar, yolları karşılaşır; görünüşte kesin ve kusursuz olan son bir uyum yaratmak için bir an birleşirler, sonra gene ayrılırlar. Her biri tek başınadır, ötekilerden ayrıdır, her birinin kendine özgü bir benliği vardır. Keman, "ben, ben'im; dünya benim çevremde döner," der; flüt, "benim çevremde," diye dayatır. Her biri de aynı derecede haklı ve aynı zamanda haksızdır; ve hiçbiri, ötekini dinlemek istemez (Huxley, 1992, s. 47).

\section{Bakhtin'de Çokseslilik, Diyalojizm ve Heteroglossia Kavramları}

Romanda çok seslilik kavramı ilk kez Rus düşünür ve edebiyat kuramcısı Mikhail Michailovich Bakhtin (1895-1975) tarafından ortaya konmuştur. Bakhtin, romanın polifonik yapısını Rus yazar Fyodor Michailovich Dostoyevski'nin eserlerinde özellikle de Karamazov Kardeşler ve Suç ve Ceza adlı romanlarında incelemiş ve bulgularını Problemy tvorçestva Dostoevskogo (Problems of Dostoyevsky's Poetics/ Dostoyevski Poetikasının Sorunları) adlı ve ilk basımı 1929 'da yapılan eserinde dile getirmiştir. Bakhtin'in (2004) saptadığı gibi

Dostoyevski çoksesli romanın yaratıcısıdır. Yepyeni bir roman türü yaratmıştır. Dolayısıyla, yapıtı önceden saptanmış çerçevelere veya genellikle Avrupa romanının muhtelif türlerine uyguladığımız tarihsel-edebi şemalara uymaz. Dostoyevski'nin yapıtlarında, sesi tıpkı alışıldık tipte bir romandaki yazarın sesi gibi kurulmuş bir kahraman ortaya çıkar. Bir karakterin kendisi ve dünyası hakkında söyledikleri, genellikle yazarın sözü kadar ağırlıklıdır; karakterin yalnızca karakteristiklerinden biri olarak nesnelleştirilmiş imgesine tabi olmadığı gibi, yazarın sesi için bir "sahibinin sesi" işlevi de görmez. Yapıtın yapısı içinde olağanüstü bir bağımsızlığa sahiptir; 
adeta yazarın söyledikleriyle beraber tınlar ve özel bir şekilde hem yazarın sesiyle hem de diğer karakterlerin eksiksiz ve eşit ölçüde geçerli sesleriyle birleşir (s. 49).

Bakhtin Dostoyevski'nin romanlarını anlatıcının konuşmalarını ve düşüncelerini romanın merkezine koyan ve böylece genellikle olayların ve karakterlerin tek bir bakış açısı ile sunulduğu ve daha da önemlisi yazarın ideolojisine göre şekillenen monolojik romanlarla kıyaslayarak Dostoyevski'nin romanlarındaki farklı yapıya dikkat çekmiştir. Bakhtin'e göre monolojik roman dışında trajedi, epik ve lirik şiir gibi türler de tek seslidir; çünkü bunlar tek bir doğru sunacak biçimde tek bir üslup çerçevesinde yapılandırılmışlardır. Monolojik söylemlerin tersine polifonik romanın söylemi "heterojen kaynaklardan edinilen farklı söylemlerin bir orkestrasyonudur" (Lodge, 1990, s. 90). Polifonik bir romanda karakterlerin ve yazarın veya anlatııının konumuna bakacak olursak buradaki en çarpıcı özelliğin monolojik romanlarda görülen "söylemsel hiyerarşi" nin (Dentith, 1996, s. 43) reddedilmesi olduğunu görürüz. Yazarın ve karakterlerin söylemlerinde hiyerarşik bir düzen olması gerektiği varsayımından hareket eden monolojik romanlar, yazarın tartışılmaz, sorgulanamaz, değişmez gerçekliği kapsayan söylemini en üst noktaya çıkarır. Bu durumda yazarın söylemi ve aynı zamanda da bilinci romandaki diğer tüm söylemleri ve bilinçleri kapsayacak biçimde yapılandırılmışıı. Tam tersine polifonik bir roman yazarsal-otoriter bir anlatı geliştirmez böylece karakteri 'öteki' konumuna getirip nesnelleștirmez. Bakhtin'e (1999) göre Dostoyevski'nin romanları farklı bakış açılarını ve diğer karakterlerin bilinçlerini içine alan tek bir bakış açısını içerecek şekilde yapılandııımamış, daha çok birinin diğerine üstün gelmediği birçok farklı bakış açısının bir etkileşimini verecek şekilde yapılandırımıştır. Bir anlamda tek bir ana karakter değil ana karakterlerin sesleri de yazarın ya da anlatıcının sesi ölçüsünde duyulmakta, tüm bu sesler aktif bir diyalog şeklinde romanda yer almaktadır. Bakhtin'e göre Dostoyevski'nin romanları tek bir ses ve görüş içermediğinden, olayları birçok değişik ve bazen de birbirine zıt bakış açıları ile sunduğundan, ve ayrıca tek bir anlam içermemesi aksine bir anlam çokluğu sunması açısından, romanın ana temasını ortaya çıkarabilmek uğruna her şeyi bilen anlatıcının bakış açısı veya sesinin karakterlerin bakış açıları ve seslerine üstün kılındığı monolojik roman türünden ayrılmaktadır. Bakhtin (2004) eserinde Dostoyevski'nin romanlarının temel özelliğinin "bağımsız ve birbirine karışmamış seslerin ve bilinçlerin çokluğu" ve "tamamen meşru seslerin" gerçek bir polifonisi (s. 48) olduğunu yazmaktadır. Polifonik roman, "çatışan ideolojik durumların bir çeşitliliğinin" ses bulduğu ve bireysel seslerin "otoriter bir yazar sesi tarafından yargılanmadan" (Lodge, 1990, s. 86) verildiği bir roman türüdür. Polifonik roman türü kendisinden önceki monolojik türdeki romanların yerleşik biçimlerini yıkar ve onun sıradan kurgulama biçimlerini reddeder çünkü "pragmatik bağlantılar [...] sonuçta karakterlerin nesne haline, yazarın tasarımındaki sabit öğeler haline gelmiş olduğunu önvarsayar" ayrıca yazarın ya da anlatıcının karakterler hakkında son sözü söyleyerek onları nihaileştirmesine neden olur. Hâlbuki polifonik roman karakterleri "yazar söyleminin nesnesi değildirler yalnızca, bunun yanı sıra kendi dolaysız anlamlandırıc söylemlerinin öznesidirler de". Bakhtin'in çoksesli roman hakkındaki önemli bir savı da şöyledir: Polifonik bir romanda "bir karakterin bilinci bir başkasının bilinci olarak, başka bir bilinç olarak verilir, ama 
aynı zamanda bir nesneye dönüştürülmez, kapatılmaz ve yazarın bilincinin basit bir nesnesi haline gelmez" (2004: 49). Polifonik roman "her biri kendi dünyasına sahip, aynı ölçüde geçerli bir bilinçler çoğulluğu" varsayımını kabul eder (Bakhtin, 2004, s. 50). Polifonik roman "kaynaşmamış bilinçler çoğulluğunu" göz ardı etmez ve kahramanların tek tek sahip olduğu "ideolojik görüşleri" "monolojik bir bütüne indirgemeye" çalışmaz (Bakhtin, 2004, s. 52). Polifonik romanın dünyası son derece kişiselleşmiş bir dünya olup, "her düşünceyi bir kişiliğin konumu olarak algılar ve yansıtır" (Bakhtin, 2004, s. 53). Polifonik roman yazarı, karakterlerine karşı oldukça nesnel bir yaklaşım geliştirmelidir çünkü "bir başkasının "Ben"inin bir nesne olarak değil ama bir başka özne olarak olumlanışı" (Bakhtin, 2004, ss. 53-54) polifonik romanda esas ilkedir. "Karakter ideolojik olarak otoriteye sahip ve bağımsız addedilir" ve kendine özgü o ideolojik anlayışın "yazarı-yaratıcısı olarak algılanır" (Bakhtin, 2004, s. 47). Bir başkasının bilincinin olumlanmasından kasıt yazarın karakterlerini eserinde kendi fikrini yansıtmak üzere kullandığı nesneler olmaktan çıkarıp, onları "kendi sesiyle bütünleştirmeden [...] nesnel ve sanatsal bir şekilde bir başkası olarak, bir başkasının kişiliği olarak" (Bakhtin, 2004, s. 57) hayal edip betimleyebilmesidir. Çünkü polifonik romanın dünyası artık özerk öznelerin dünyasıdır. "Yapıtın kendisinin kahraman ile yazar arasına bir mesafe koyması" koşulu ve "kahramanı yaratıcısıyla birleştiren göbek bağının kesilip" (Bakhtin, 2004, s. 103) atılması polifonik bir romanın ayıııc bir özelliği olarak söylenebilir. "Monolojik bir tasarımda kahraman kapalıdır ve anlamsal sınırları kesin biçimde çizilmiştir: kahraman ne ise odur ve olduğu şeyin içinde [...] edimde bulunur, deneyimler, düşünür ve bu sınırlar içinde bilinçlidir [...] kendi karakterinin, tipikliğinin, mizacının dışına çıkamaz" (Bakhtin, 2004, s. 103). Hâlbuki polifonik roman yazarı Wayne C. Booth'un (2004) da belirttiği gibi

Karakterlerine sahiden teslim olur ve onların kendisininkinden başka şekillerde konuşmalarına izin verir. Kahramanlar artık yazarın mütehakkim bilincine indirgenmez; [...] karakterler oynadıkları roller sayesinde tamamen bilinen nesneler olarak gösterilmek ve sonra da işlerini bitirmiş görülüp bir kenara atılmak yerine, eksiksiz özneler olarak kabul edilirler, asla tam olarak tanımlanamayan veya tüketilemeyen "bilinçler" olarak gösterilirler (s. 19).

İşte tam da bu özellik romanı polifonik yapmakta ve bundan dolayı roman açıkuçluluk, çok-anlamlılık gibi modernist özellikler göstermektedir. Bakhtin (2004) polifonik roman yazarının insan hakkındaki son sözü hiçbir zaman söyleyemeyeceğini çünkü bir insanda daima sadece kendisinin kendisi hakkında açığa vuracağı bir şeyler olduğunu vurgulamaktadır (s. 111). Bir başka deyişle polifonik romanda "hiç sonlandıııcı, açıklayıcı söz" bulunmamakta "karakterlerin sesleri ile anlatıının sesi bitmeyen bir diyalog halinde romanda yer almaktadır" (Dentith, 1996, s. 42). Özetlersek, polifonik bir romanda artık sadece anlatıının sesi duyulmamakta, bir sesin diğerine göre üstünlüğü tartışılamamaktadır; olaylar tek bir anlatııının bakış açısıyla verilmediğinden roman artık tek bir doğru sunmamaktadır. Bunun yerine bazen birbirini tamamlayan çoğu zaman birbiriyle çelişen değişik seslerin bir arada ve etkileşim içinde bulunması ile zamandan zamana, kişiden kişiye ve hatta aynı kişinin yaşamının farklı dönemlerinde bile 
kişinin farklı deneyimlerine bağlı olarak değişiklik gösterebilen öznel gerçekler sunmaktadır. Yalnız polifonik romanın sadece kişisel gerçekleri sunan bir roman türü olduğunu düşünmek hatalı olur. Yani karakterlerin sesleri diğer karakterlerin ve aynı zamanda anlatııının sesleri ile çeşitli şekillerde karışmadığı veya bir arada bulunmadığı sürece romanı polifonik yapan bir özellik değildir. O zaman karakterlerin tek tek söylemleri göreceli söylemler olmaktan öteye gitmeyecektir ki polifoni görecelik demek değildir. Bir kişinin öznel doğrusu diğer kişi ya da kişilerin doğrusu ile bir arada bulunduğunda ortaya çıkabilecek ve anlam kazanabilecektir. Karakterlerin tek tek sesleri gibi bilinçlerinin de diğer bilinçlerle bir arada olmadığı, onlarla etkileşime girmediği yani tek olma durumunu yansıtan bir romanın çoksesliliğinden bahsedilemez. Bilincin bu özelliğini Bakhtin (2004) şu şekilde ifade etmektedir. "Tekil bir bilinç contradictio in adjecto'dur. Bilins esas itibarıyla çoğuldur" (s. 376). Yani "tekil bir bilinç" ifadesi kendisiyle çeliş̧mektedir, bilinç zaten tekil olamaz. O halde polifonik bir romanda aktarılan bilinçler bir şekilde diğerlerinin bilinciyle etkileşim içinde olmalıdır. Seslerin, söylemlerin ve bilinçlerin etkileşimini sağlayacak şey ise romanın diyalojik düzlemi ve bu seslerin ve kahramanların diyalog veya bilinçlerindeki tınıların orkestrasyonunu gerçekleştirecek kişi de yazar ya da (yazar-) anlatıcı olacaktır.

Bakhtin'in teorisindeki çokseslilik kavramının aslında onun diyalojizm, başka bir deyişle söyleşimsellik ile ilgili teorisinden kaynaklandığı açıktır. Polifonik bir roman farklı sesleri diyalojik bir düzlemde eşzamanlı olarak sunar. $O$ halde polifonik bir romanın söylemi diyalojiktir. Diyalojizm "dilin kendisinin özde diyalojik yapısı"ndan (Lodge, 1990, s. 86) kaynaklanmaktadır. Bakhtin'e göre "birçok sesin çoktan nüfuz etmiş olduğu bir dille - özel değil toplumsal bir dille konuşarak bilinç sahibi oluruz. Daha en baştan "çok-dilliyizdir"; ebeveynlerden, klandan, sınıftan, dinden, ülkeden türemiş bir toplumsal diyalektler çeşitliliğine vâkıf olma sürecine çoktan girmişizdir" (Booth, 2004, s. 17). Bakhtin (1981) bir diyalogda sözün "doğrudan ve apaçık bir şekilde yanıt olacak sonraki kelimeye doğru yönlendirildiğini" ve "bir yanıt gerektirdiğini, beklediğini ve kendini yanıt yönünde yapılandırdığını" (s. 280) belirtmektedir. Roman ise okuyucusuna işte bu süreci yansıtmaktadır. $O$ halde anlam da söyleşimselliğin dışında aranacak belli, kesin bir doğruyu sunmayacak aksine diyalojizmin dinamikliği içinde aranacaktır. Lodge (1990) diyalojik söylemde anlamın, "konuşan özneler arasındaki, metinlerle okuyucular arasındaki" ya da "metinlerin birbirleri arasındaki etkileşimin diyalojik sürecinde bulunabileceği" (s. 86) görüşündedir. Bakhtin'e göre söylem, "her biri sadece sözsel olmayıp sosyal bir olgu olan birçok sesin yahut da söylemin diyalojik etkileşim alanıdır" (Abrams, 1999, s. 63). O halde roman kişisinin farklı toplumsal bağlamların dillerinden oluşmuş konuşması bağımsız bir bireysellik ifade etmez; roman karakterinin söylemi de aynen gerçek yaşamdaki insanların söylemleri gibi daima başka söylemlerden etkilenir, onları içerir ve onların izini taşır. Kişi sözlerini bu söylem çeşitliliği içinden seçerek konuşmasını şekillendirir. Bu durum ise kişinin karakteri veya özelliklerini açığa çıkarır. Öyleyse roman karakterinin kişiliği ve özellikleri de diyalojik düzlemde ortaya çıkar. Bakhtin'in 'diyalojik imgelem/söyleşimsel hayal gücü (dialogic imagination)' teorisi Dostoyevski'nin romanlarında diyalojizmin rolünü analiz etmesiyle ortaya çıkmış ve daha sonra polifonik roman anlayışıyla özdeşleşmiş 
bir teoridir. Bakhtin için dil her zaman diyalojiktir ve romanda diyalojizm ise sadece, karakterler arasında gerçek anlamda diyalog olması anlamına gelmez. Diyalojik bir romandaki karakterlerin orijinal, kendine özgü dünya görüşleri ve kişilikleri olması yeterlidir. Romanda diyalojik düzlem bazen karakterler arasındaki diyaloglar vasıtasıyla bazen de iç sesler (monologlar) vasıtasıyla sağlanabilir. Örneğin bir roman kişisi fiziksel olarak yanında olmayan, somut bir şekilde konuşma bağlamında bulunmayan kişi veya kişilere de seslenebilir, yönelebilir yahut da yazar eserinde hayali okuyucusuna seslenir, onunla iletişime girer; dolayısıyla roman bu yönüyle de diyalojik bir söylemdir. Bir edebi yapıt okuyucusuna seslenebildiği gibi diğer metinlere de seslenebilir. Burada da metinlerarası bir diyalojizmden yani metinlerarasılıktan (intertextuality) bahsedebiliriz. Romanda monolog gibi görünen bir konuşma bile diyalojik olabilir. Çünkü kişinin kendi sesine diğer karakter(ler)in sesi de karışabilir; onların diyaloglarının tınıları karakterin sesinde duyulabilir. Başka bir alternatif ise bu diğer sesin roman karakterinin kendi içsel sesi olabilmesidir. Diyalojizm nasıl sağlanırsa sağlansın, sözün anlam kazanabilmesi onun diyalojik bir süreç içinde bulunmasına bağlıdır. 'Bakhtin Çevresi'nin bir üyesi olan V. N. Voloshinov'un adıyla yayımlanan ve kısmen Bakhtin'in kendisi tarafından yazıldığı düşünülen (Lodge ve Wood, 2000, s. 104) Marxism and the Philosophy of Language adlı yapıtta Bakhtin (veya Voloshinov) (1973) dilin diyalojik yapısı konusunda şöyle yazar: "Dilin canlılı̆ı, sadece ondan yararlananların diyalojik etkileşiminde görülür. Diyalojik etkileşim, diyalojik ilişkilerle içine girdiği dilin yaşamının gerçek alanıdır" (ss. 102-103). Bakhtin'e (veya Voloshinov'a) (1973) göre hiçbir söz veya cümle sadece söyleyene ait değildir, söyleyenle dinleyen arasındaki etkileşim sonucunda oluşur; çünkü "söz çift yönlü bir edimdir. Anlamı kimin sözü olduğu ve kim için anlam taşıdığıyla eşit biçimde belirlenir. Söz tam olarak konuşan ile dinleyen, seslenen ile seslenilen arasındaki karşılıklı ilişkinin bir ürünüdür" (s. 86). Ayrıca "bir sözün anlamı tamamıyla bağlamı tarafından belirlenir. Aslında bir sözün içinde kullanıldığı bağlamı kadar anlamı vardır" (Voloshinov, 1973, s. 79). O halde kişinin söyleminin sosyolojik ve kültürel boyutundan da söz edilebilir çünkü söylem belli bir kültürel çevrede üretilmiş, üretilmekte ve üretilecek olan her söylemle ilişkilidir. Bu durumda söyleyen hiçbir zaman bağımsız değil, söylem de hiçbir zaman özgür ve kendine özgü değildir. Diyalojizm söylemler arası ilişkiyi gerekli kılar ve sözler bu ilişki ile anlama dönüşür.

Sözler birbiriyle ilgisiz olmadığı gibi, kendilerine yeterli de değildir; birbirinin farkındadırlar [...] Her söz konuşmaya dayalı iletişim alanının sosyalliğiyle bağlı olduğu diğer sözlerin yansımaları ile doludur. [...] Her söz diğerini çürütür, olumlar, tamamlar, [...] onları bir şekilde dikkate alır (Bakhtin, 1986, s. 91).

Bakhtin için diyalojizm aynı zamanda roman dilinin 'çift-sesli' olmasını da ifade eder. "Bir söylemde iki anlamsal niyet, iki ses" belirebilir. Bakhtin (2004) bu durumu şöyle açıklar: "yazar zaten kendisine ait bir niyeti olan ve bu niyeti muhafaza eden bir söyleme yeni bir anlamsal niyet katarak bir başkasının söylemini de kendi amaçları için kullanabilir" (s. 261). Bakhtin hukuk, tıp, eğitim vb. gibi sosyal edebiyat, sanat, tarih vb. kültürel söylemlerin romanın yapısında 
bir araya geldiğini belirtir. Farklı söylemlerin, farklı toplumsal ve kültürel dillerin bir arada olduğu romanda yazarın diline eşlik eden farklı diller bulunmaktadır. 0 halde roman birçok dilin diyalog halinde olduğu melez bir yapıdır diyebiliriz.

Diyalojik bir roman monolojik romanla karşılaştırıldığında doğal olarak monolojik bir romanda görülen anlam sabitliklerinin diyalojik bir romanda barınamayacağı söylenebilir. Çünkü diyalojik roman çoksesli, çok katmanlı, çok dilli, çeşitli söylem biçimlerini bir arada ve daima etkileşim içinde sunabilen bir türdür. Polifonik roman kanonlaşmış türlerin "organik malzeme bütünlüğünü" ihlal edişiyle "en farklı ve birbiriyle bağdaşmaz öğeleri romansal kuruluşun bütünlüğünde" birleştirmesiyle ve "anlatının bütünlüklü ve birleşikli dokusunu" (Bakhtin, 2004, s. 59) yıkmasıyla monolojik romandan radikal bir şekilde ayrılır. Leonid Grossman'ın Dostoyevski'nin romanlarında ayırıcı bir özellik olarak gördüğü bu "romansal kompozisyon" polifonik romanların aslında önemli bir özelliğidir. Grossman şöyle der:

Zıt kutuplarda bulunan anlatı öğelerini felsefi bir tasarımın bütünlüğüne [...] tâbi kılmak.Felsefi itirafları ve suçla dolu serüvenleri tek bir sanatsal yaratışta birleştirmek, dinsel dramı bir bulvar romanının olaylar zincirine katmak [...] bir serüven anlatısının tüm beklenmedik ve ani durum değişikliklerine maruz bırakmak tüm bunlar Dostoyevski'nin kendisine verdiği sanatsal görevlerdir ve böylesine karmaşık yaratıcı yapıtlar vermesine esin kaynağı olmuşlardır (aktaran Bakhtin, 2004, s. 59).

Polifonik bir romanda, monolojik romanda görülen 'olay örgüsü' şeklindeki bağlantılara da yer verilmez. Çünkü bu tür bağlantılar karakterleri yazarın amacına hizmet etmek üzere yaratılmış nesneler konumuna getirir. "Bu tür bağlantılar nihaileştirilmiş insan imgelerini monolojik olarak algılanan ve kavranan bir dünyanın bütünlüğü içinde birbirine bağlar ve birleştirirler; her biri kendi dünyasına sahip, aynı ölçüde geçerli bir bilinçler çoğulluğu varsayımı yoktur." O halde polifonik bir roman monolojik türdeki romanların alışılmış anlatı biçimlerinden farklı bir yol izleyip farklı anlatım teknikleri geliştirmelidir. Bu "yazarın, bir anlatıcının veya karakterlerin hepsinin anlatısı için de aynı ölçüde geçerlidir" (Bakhtin, 2004, s. 50). Dostoyevski'nin romanında açımlanan şey, "tek bir yazar bilincinin aydınlattığı tek bir nesnel dünyadaki karakterlerin ve yazgıların çokluğu değildir", daha ziyade "her biri eşit haklara ve kendi dünyalarına sahip bir bilinçler çoğulluğu"nun bir olayın bütünlüğünde birbiriyle tutarlı olmaksızın bir araya getirilmesi ama yine de kaynaşmamasıdır (Bakhtin, 2004, ss. 48-49). Bakhtin'e (1999) göre Dostoyevski'nin bir roman yazarı olarak özgünlüğü romanını çoksesli diyaloglar tarzında kurgulamış olmasında yatar. Roman kahramanlarının her birinin dünyaya ve yaşama farklı bir bakış açısı, kendini ve yaşamı yorumlayacak kendine özgü bir duruşu vardır. Anlatıcının sesini de kahramanlarının sesini de eşzamanlı olarak duyurarak birinin diğerinden daha üstün olmadığı çoksesli bir özgürlük ortamı yaratır. Dostoyevski karakterleriyle görülmemiş bir ilişki kurar. "Sessiz köleler yaratmaz, [...] tersine, yaratıcılarının yanında durabilen, onunla aynı görüşü paylaşmamaya muktedir olan, hatta ona karşı gelebilen özgür insanlar yaratır" (Bakhtin, 2004, s. 48). Clark ve Holquist, (1984) Bakhtin'in Dostoyevski'nin romanları konusundaki bu 
düşüncelerini haklı olarak çoksesli romanın da önde gelen bir özelliği olarak görürler. Dostoyevski'nin bu özelliğinin sadece tek tek karakterlerinin farklı fikirleri, ideolojileri savunma güçleri olmasından değil onların her birinin birbirlerinin dünyası ile ilişki içinde olmasından kaynaklandığı ve her bir karakterin bilincinin diğer karakterlerin bilinçleriyle bir anlamda bir arada olduğu, diğer bilinçlerden de haberdar olduğu görüşlerini savunurlar (s. 241). Başka bir deyişle çok sesli bir romanda karakterlerin düşüncelerini yansıtması ve dolayısıyla seslerini duyurması diyalojik bir düzlemde gerçekleşmektedir. Bakhtin (2004) bilinçlerin etkileşimi konusunda şöyle söyler: "Bilinç asla kendi çekimine girmez, diğer bir bilinçle yoğun bir ilişki içinde bulunur daima. Bir karakterin her deneyimi, her düşüncesi içsel olarak diyalojiktir, polemikle yüklüdür, mücadeleyle doludur ya da aksine kendi dışından gelecek esinlere açıktır" (s. 81).

Bakhtin'de heteroglassia kavramına gelince, Bakhtin, The Dialogic Imagination adlı yapıtında diyalojizm kavramını heteroglassia kavramıyla geliştirir. Bakhtin'e göre bir metni oluşturan şey dilde var olan ifadeler ve konuşma türleridir. Graham Allen (2000) Bakhtin'de heteroglossia kavramını dilin kendi içinde kişinin kendi sesi ile diğer birçok sesi birlikte barındırma yeteneği olarak tanımlamaktadır (s. 29). Dil heteroglottur çünkü içinde hem "geçmiş sözleri" hem de "gelecek cevapları ve etkili kullanımları" barındıır; "heteroglot bir ifade dilin diyalojik doğasını açıkça gösterir" (Allen, 2000, ss. 213-214). Bu anlamda monolojik bir söz "izole olmuş", "bitmiş", "kapalı" (Voloshinov, 1973, ss. 72-73) olması açısından heteroglot özellik ile zıtlık teşkil etmektedir. Bakhtin'in (1981) de belirttiği gibi "tarihsel oluşumunun herhangi bir döneminde dil baştan aşağı heteroglottur" (s. 291). Çünkü "her bir dönem ve her bir sosyal grubun insan davranışının ideolojik iletişimi için konuşma biçimleri repertuarı olmuştur ve olmaktadır" (Bakhtin, 1973, s. 20). "Kelimeler daima davranış veya ideolojiden kaynaklanan içerik ve anlamlarla doldururlar" (Voloshinov, 1973, s. 70). Dolayısıyla dil belli bir tarihsel süreç içinde ve toplumsal olarak değişiklik gösterir; o yüzden de sosyal grup ve sınıflara, mesleklere, sanat dallarına vs. ait olan çok çeşitli diller/söylemler oluşabilir. Bu düşünce dilin orijinal ve bireysel olduğu görüşünü reddeder. Heteroglossia, basitçe çok dillilik, çok söylemlilik veya çok sözlülük şeklinde tanımlanabilir. Bir dil içinde, günlük dil yani konuşma dili ile yazı dili, resmi dil, sanatsal dil, mahkeme dili, jargon, argo, şive, ağız, lehçe gibi dil çeşitleri barındırır. Roman ise işte bu değişik dilleri yapısı içinde barındıran bir türdür. Yani roman hem yazılı hem de sözel olarak kullanılan dilden değişik seslerin ve türlerin veyahut da diyalektlerin ve konuşma biçimlerinin bir araya getirildiği ve belli bir şekilde düzenlendiği bir türdür. Bakhtin'e göre romanın söylemi de dilin bu değişken kullanımlarını içermesinden dolayı heteroglottur. O halde roman yazarının da romanda dili yaratıcı bir şekilde kullandığı söylenemez. Tek bir kişinin söylemi birçok söylemin karışımı, diğer söylemlerden etkilenmiş, başka söylemlerin izini taşıyan heterojen bir söylemdir. O yüzden yazarın söylemi de orijinal bir söylem değildir. Eserin orijinalliği yazarın bu değişik söylem biçimlerini ve değişik dil kullanımlarını nasıl bir araya getirdiğindedir. 


\section{Ses Sese Karşı'da Polifoni, Diyalojizm ve Heteroglossia}

Ses Sese Karş/da polifonik yapının Huxley'nin birçok roman kişisi yaratarak, geleneksel gerçekçi romanlarda olduğu gibi bir öyküyü başından sonuna kadar anlatmak yerine karakterlerin her birinin öykülerini onlara aynı uzaklıkta kalarak romanın diyalojik kurgusu içinde vermesiyle sağlandığı söylenebilir. Huxley'nin roman kişilerini gerçek yaşamında tanıdığı kişilerden esinlenerek yarattığı bilinmektedir. Örneğin, D. H. Lawrence Mark Rampion'ın kişiliğinde verilmiş, Denis Burlap ise Middleton Murray'nin edebi kişiliği olarak yansıtıımıştır. Romandaki roman yazarı Philip Quarles ise Huxley'nin kendisidir. Fakat burada bizim için önemli olan bu kişilerin çoğunun modern dünyanın getirdiği yaşamla, modern dünyanın insana verdikleri yahut da insandan aldığı değer yargılarıyla şekillenmiş olmasıdır. "Bu kişilerin çoğu, can sıkıntısı içinde bunalan, neye inanacaklarını ve hangi değerlere göre kendilerine bir yön seçeceklerini bilmedikleri için, bocalayıp duran, umudunu yitirmiş, orta ya da yüksek sınıfın içi içine sığmayan aydınlarıdır" (Urgan, 1992, s. 10). Bu anlamda roman herhangi bir amacı olmayan ve "savaş sonrası Londra'sında" yaşayan insanların "anlamsız varlığını" resmetmekte ve "özellikle de insanın çok karmaşık, daha fazla mutluluk arayışı içinde 'duygu ve akıl' arasında bölünen" bir varlık olduğunu göstermektedir (Burgess, 1974, ss. 219-220). Arnold Kettle (1969) ise Ses Sese Karş/yı sanatsal özelliğinden daha çok sosyolojik açıdan okunabilecek romanlar grubuna koyar ve bir nevi kötümserlik havası yansıttığına işaret ederek, romanın bu özelliğinin yansıttığı dekadan toplumdan kaynakladığını belirtir. Daha da önemlisi tüm bu kötümserlik havası yaratan roman yazarlarının, Huxley de dâhil, romanlarında resmettikleri toplumsal değerlerin içinde gark olduğunu söyleyerek "onlar sadece dekadanı yansıtan yazarlar değil, kendileri de dekadan yazarlardır" şeklinde bir yorumda bulunur. Kettle (1969) daha sonra bu kötümserlik ve dekadanlığın da birer insan deneyimi olduğunu ve bunların da yansıtılması gerektiğine işaret eder (ss. 149-150). İşte bizim de katılacağımı bu görüşten hareketle denebilir ki Huxley modern yaşamın bu özelliklerini romanında çeşitlilik yaratmak üzere kullanmıştır. Huxley gerçek yaşamdaki çok zengin sözsel düzlemi romanında yaratmak için öncelikle birbirinden oldukça farklı karakterler çizmekte ve bunların değiş̧ik öykülerini eşzamanlı olarak yine karakterlerin değişik sesleriyle vermektedir. Huxley romanında polifonik özelliği yaratmak için doğal olarak çok sayıda anlayış, görüş, bakış açısına sahip olan çok sayıda karakter yaratmışır. Ses Sese Karş/nın aynı zamanda bir fikir romanı olduğunu ve bunun romanın polifonisine katkıda bulunduğunu belirtmiştik. Bir fikir romanında yazarın amacı birbiriyle çatışan veya birbirini tamamlayan fikirleri aynı düzlemde vermektir. Romanda Huxley'nin sözcülüğünü yapan roman yazarı Philip Quarles fikir romanını şöyle betimler: "Düşün romanı; sözcülüğünü ettikleri düşüncelerden yararlanarak, romandaki insanların kişiliğinin anlaşılabilmesi için elinden geleni yapmalı. Kuramlar; duyguların, içgüdülerin, ruhsal durumların bir rasyonalizasyonu olduğu ölçüde yapılabilir bu" (Huxley, 1992, s. 475). Ses Sese Karş̧ıın bir fikir romanı oluşu, roman karakterlerinin bir ölçüye kadar belli düşüncelerin kişileştirilmiş hali olarak algılanmasına neden olmaktadır, yani karakterler temsil ettikleri düşüncenin dışına çıkmayan basmakalıp karakterler olarak gözükmektedirler. Örneğin Lord Edward Tantamount, topluma inemeyen 
kendini toplumdan soyutlayan bilimi, Illidge sosyalist düşünceyi, Spandrell kötülüğü ve nihilizmi, Philip Quarles kuru bir akılcılığı, Elinor modern çağların duygusallığını, Mrs. Quarles dini düşünceyi, Lucy sadece özgür seks ile özgür olunacağını sanan kadını, Carling ise ikiyüzlü dindarlığı temsil etmektedirler. Huxley bilim, tıp, zooloji, botanik, genel olarak sanat, müzik, edebiyat, mitoloji, felsefe, psikoloji, metafizik, din, sosyoloji, tarih, politika gibi birçok alanlardan yararlanarak dünyaya, yaşama farklı bakabilen karakterler yaratmıştır. Bir makalesinde, Huxley'nin Ses Sese Karş/da anlam çokluğunu nasıl yarattığı ve bu anlam çokluğundan nasıl bir bütüne ulaştığını araştıran James Quina, romanın barındırdığı konu çeşitliliğine dikkat çekmektedir. Ses Sese Karş/da "matematik, fizyoloji, anatomi, moleküler hareket, zaman, organik evrim ve Newton'un ışık teorileri ile ilgili imgelerin estetik, etik deneyimler, dini inanışlar ve insani değerlerle ilgili imgelerle çakıştırılığını" (Quina, 1992, s. 430) vurgulamaktadır. Roman karakterlerinin çoğu farkı bilim ve sanat görüşlerinin ya da yaşamın kendilerine sağladığı farklı bakış açılarından dolayı farklı dünya görüşlerine sahip olabilmişlerdir. Başka bir deyişle Huxley var olan değişik görüşlerin ve bilgi alanlarının çoğulluğu araciığıyla karakterlerini değişik görüşlerle donatmıştır. Dolayısıyla romanda bir ceninin anne karnındaki gelişiminden bahsedilebildiği gibi (Huxley, 1992,s. 5), tarih öncesi çağlarda yaşayan dinozorların Latince isimleriyle anılabildiği de görülmektedir (Huxley, 1992: 336). Roman, fosfor maddesinin topraktan azalması ve sonra da yok olmasına ilişkin bilimsel görüşler ve matematiksel hesaplar (Huxley, 1992, s. 98) ya da çok sesli müzikle ilgili teknik bilginin yanı sıra (Huxley, 1992, s. 9), romanın nasıl bir edebi tür olması gerektiğine ilişkin görüş de içermektedir (Huxley, 1992, ss. 546-551). Romandaki fikir çeşitliliğini son kez örnekleyecek olursak; roman bir yandan bir viyolonselin yayının ve tellerinin neden yapıldığına ilişkin bilgi verirken (Huxley, 1992, s. 48) öte yandan insanın sesleri nasıl duyduğuna ilişkin bilgi de içermektedir (Huxley, 1992, s. 57). Ayrıca akıl-duygu çelişkisi, ikiyüzlülük, ahlâksal anlamda alçaklık, ölüm, cinayet, intihar, aşk, evlilik, cinsellik, seks, erotizm vb. gibi insana ve yaşama ilişkin birçok olgunun da romanda yer aldığı görülmektedir. Burada Virginia Woolf'un "Modern Fiction" adlı makalesinde modernist romanın konusunun neler olabileceğine ilişkin görüşünü hatırlatmakta yarar görmekteyiz. Woolf (1986) "her şey romanın konusu olabilir, her duygu, her düşünce; beynin ve ruhun her özelliği hakkında yazılabilir; hiçbir algı yanlış olmaz" (s. 1999) der. Belli ki Huxley Woolf'un bu anlayışını bir hayli geliştirerek bunların hepsini birden aynı romanın konusu yapmıştır. Huxley (1931) edebiyatın işlevini "her yöne sonsuz şekilde uzanan birbiriyle ilişkisiz şeyler, olaylar ve düşüncelerin büyük bir okyanusu" hakkındaki "Bütünsel Gerçeği" yansıtmak olarak görür (s. 185). Romanda çokseslilik konusuna dönecek olursak, Huxley farklı seslerin eşzamanlı olarak verilebilmesi için hem romanda ana karakter diyebileceğimiz on dokuz roman kişisi yaratmış hem de karakterlerin söylemlerini diyalojik hale getirmiştir. Romanda diyalojik bir düzlem oluşturabilmek için sık sık onları kalabalık ortamlarda konuşturmuş, onların bilinçleri ve söylemlerine diğer karakterlerin bilinç ve söylemlerini yansıtmıştır. Romanda her bir farklı karakterin farklı bakış açıları geliştirerek olaylara farklı bakması sağlanmış, böylece her bir karakterin farklı doğrulara sahip olmaları sağlanmıştır. Durum böyle olunca, yani romana 
çoksesli bir anlatı hâkim olunca, hiçbir gerçeklik kavramı bir diğer insanın gerçeklik kavramından üstün olmayacak ve dolayısıyla her bir gerçeklik kavramı diğer bir gerçeklik kavramı kadar geçerli olacaktır. Huxley romanını birçok paralel öykü yaratacak biçimde yapılandırmıştır. Romanda roman yazarı Philip kurgusal çokseslilik konusundaki düşüncelerini açıklarken bu paralelliğe de değinerek, romanda olması gereken çoksesliliği şöyle dile getirir:

Gereken tek şey, romanda yeterince kişi olması ve kontrpuanı andıran koşut konular bulunması. Jones karısını öldürürken, Smith parkta bebek arabasını sürüyor. Sırayla önce bir temayı, sonra başka bir temayı ele alıyorsunuz. Makamdan makama geçişler ve çeşitlemeler daha ilginç, ama daha güç. Romancı durumları ve kişileri birkaç kat arttırarak bu geçişleri yapabilir. Birkaç kişinin başka başka biçimlerde âşık oluşunu, ölüşünü ya da dua edişini gösterir - yani değişik kişilerin aynı sorunu çözümlemelerini anlatır - ya da tam tersini yapar; birbirine benzeyen kişileri, değişik sorunlarla karşılaşmalarını ele alır. Böylece işlediğiniz temanın tüm aşamalarında geçişler, değişik makamlarda çeşitlemeler yapabilirsiniz. Bir yol daha var: Romancı, [...] öykünün çeşitli yanlarını - yani duygusal, bilimsel, ekonomik, dinsel, fizik ötesi, vb. yanlarını - ele alır (Huxley, 1992, s. 474).

Philip'in Elinor'la Hindistan gezisi dönüşünde yolculuk yaptıkları geminin güvertesinde oturuken duyduğu seslerin çeşitliliği ona çoksesli romanını yazma konusundaki ilk fikirleri vermiştir. Philip yanlarından geçip giden insanların konuşmalarından duyduğu bölük pörçük ifadeleri kastederek şöyle söyler:

Bu camisoles en flanelle'ler [çocuklar için faniladan yapılmış frenkgömlekleri], soğan turşuları, yamyam adaları piskoposları konumuzla gerçekten ilgili; çünkü olaylara yeni bir gözle bakabilmek için, onların çok çeşitli olduğunu görebilmek gerek. Gözler de çeşitli olmalı görülen şeyler de. Örneğin, biri, olayları piskoposlar açısından yorumluyor; ötekisi, faniladan yapılmış frenkgömleklerinin fiyatı açısından; bir başkası da Gulmerg'den gelen bayan gibi," (uzaklaşan grubu başıyla gösterdi) "hoş vakit geçirmek açısından. Bunların dışında biyoloji uzmanları var, kimyagerler var, fizikçiler var, tarhçiler var. Mesleklerine göre her biri, olayların ayrı bir yönünü, gerçeğin ayrı bir tabakasını görüyor. İşte benim yapmak istediğim, tüm bu gözlerle aynı anda bakabilmek. Dindar gözlerle, bilimsel gözlerle, ekonomik gözlerle, sıradan bir insanın gözleriyle... (Huxley, 1992, s. 311)

Huxley (1992) romanın yirmi dokuzuncu bölümünde farklı bakış açılarının çatışmasını vermekte ve böylece yaşamın kendisinin zaten bu değişik anlayışları içerdiğini örneklemektedir.

Hyde Park'da, haziran ayının bir cumartesi günü.

Yeşiller giyip, kılıç kuşanan Everard Webley, Bucephalus adlı atına binmiş, Britanyalı bin Hür Adama nutuk çekiyordu. Hür adamlar, [...] askerce bir düzenle [...] yürüyerek, Marble Arch'a varmışlardı. Parka girerlerken; tıbbın gelişmesi uğruna canlı hayvanlar üzerinde deney yapanları protesto etmek amacıyla toplanıp yürüyüş yapan bir alay insanla burun buruna gelmişlerdi. [...] Yürüyenler birbirine karışmış; "Britanyalı Grenadier"ler marşını çalan bando ile "Bütün İmanımla sana Bakıyorum, Ey Çarmıha Gerilen Kuzu" adlı dinsel şarkıyı çalan öteki bandonun çarpışmasından ortaya uyumsuz bir müzik çıkmış; üstünde "küçücük köpeklerimizi koruyunuz" yazııı pankartlarla "Britanyalılar asla köle olamaz" pankartları ve "bunlar doktor mu yoksa 
şeytan mı" pankartlarıyla "sosyalizm zorbalık demektir" pankartları birbirine girmişti (ss. 537-538).

Ses Sese Karş/da polifonik yapıyı sağlayan farklı bakış açılarının hem tek tek ele alınınca hem de bir bütün içinde değerlendirildiğinde ne kadar farklı şeyler verebildiği "Philip Quarles'ın not defterinden" Bölümü'nde açıklığa kavuşmaktadır:

Sunday Pictorial gazetesinde Everard Webley'in ağzı açık bir resmi: Gerilmiş bir yüzün ortasında, avazı çıktığı kadar böğüren karanlık bir delik. "B.B.F. in kurucusu ve önderi Mr. E. W. Cumartesi günü Hyde Park'da, Britanyalı Hür Adamların bir alayına bir söylev verdi." İşte bu olaydan kala kal bu kaldı: Demagojinin bu gülünç ve korkunç simgesi. Anırmak için açılan bir ağız. Ne iğrenç şey!

Oysa, insanı gerçekten etkileyen bir şeydi bu. Avaz avaz böğürürken pek soylu görünüyordu Webley. Kıratının üstünde heybetli bir heykel gibiydi. Fotoğraf makinesi, sürekli bir olayın tek bir anını seçerek, Webley'yi çirkin bir bostan korkuluğuna çevirdi. Haksızlık mı bu? Yoksa fotoğraf makinesinin gördüğü gerçek de, benim gördüğüm mü yanlış? Çünkü insanda olumlu bir izlenim bırakan o sürekli olay, fotoğraf makinesinin saptadığı o çirkin anların birikiminden oluştu ne de olsa. Bir bütün, o bütünü oluşturan parçalardan bambaşka olabilir mi? [...] Everard'ın fotoğrafı gerçek bir sorun koyuyor ortaya. Milyonlarca iğrenç saniyeden, görkemli bir yarım saat çıkıyor meydana (Huxley, 1992, ss. 546-547).

Everard Webley'nin özgür girişimi destekleyen ve sosyalizme karşı gelen Britanyalı Hür Adamlar partisine mensup yaklaşık bin kadar kişiye hitaben yaptığı konuşma önce yazar-anlatıcının bakış açısıyla verilmektedir. Anlatıcı, okuyucu olarak çıkarım yapabildiğimiz kadarıyla Webley'nin güzel bir ses tonu ile kendinden son derece emin, hitabet yeteneği güçlü, kalabalığı kontrol altında tutabilen ve gerektiğinde coşturabilen, ikna edici konuşma yeteneği olan ve beyaz atının üzerinde yükselerek konuşan intişamlı bir Webley karakteri göstermektedir (Huxley, 1992, ss. 538-541). Olay daha sonra kapitalizm karşıtı görüşte olan ve Webley'nin söylevini sabote etmeye çalışan Illidge'in bakış açısıyla ve daha sonra Webley'nin sevdiği ve elde etmeye çalıştığı ve yazar Philip Quarles'ın eşi Elinor Quarles'ın bakış açısı ile verilmektedir. Son olarak da Quarles'ın gazetedeki bir resim ve haberle öğrendiği bu olaya karşı tepkisi ve olayı değerlendirmesi verilmektedir. Burada gazetenin de bakış açısı olduğunu unutmamak gerekir.

Ses Sese Karş/da öykülerini okuduğumuz ve bakış açılarını gördüğümüz roman kişileri (ki bunları daha önce iki gruba ayırmıştık, burada da birinci grubu oluşturan ve hepsine birden ana karakter diyebileceğimiz kişilerle başlayacağız) romanda göründükleri sıra ile şunlardır: Walter Bidlake, John ve Janet Bidlake'in oğlu, Edebiyat Dünyası dergisinin yöneticisi Denis Burlap'ın yardımcı editörü. Marjorie Carling, evli bir kadın ama Walter Bidlake'in sevgilisi; önce romantik bir âşık sonrasında ise huzur bulabilmek için Hıristiyanlığa dönen bir kişilik olarak görünmekte. Elinor Quarles Philip Quarles'ın eşi. Eşinin duygusuzluğundan yakınan, cinsel anlamda soğuk bir kadın olup yeni aşk arayışlarını Everard 
Webley ile yaşama teşebbüsünde olan fakat Webley'in ölümü ve kendi küçük hasta oğlunun ölümü ile acılı bir kadın haline gelen bir roman kişisidir. Philip Quarles, Sidney ve Rachel Quarles'in oğlu, Elinor'un eşi ve roman yazarı. Philip Quarles aydın birisi, toplum, bilim ve roman yazma konularında Huxley'nin düşüncelerini aktarmak için yarattığı ve aynı zamanda romanın bir 'düşünce romanı' olmasını sağlayan bir karakterdir. Çünkü Huxley roman türü üzerine görüşlerini bu karakter aracılığıyla vermektedir. Quarles duygusal yönünün zayıf olduğunu kendisi de bilmekte; akılc bir kişi, her şeyi analitik, bilimsel veya felsefi terimlerle düşünmekte. Ayağının aksak olması nedeni ile hiçbir zaman spor yapamamış ve eşi de dâhil insanlarla düzgün ilişki kuramamış sosyal yönü zayıf birisidir. Lucy Tantamount, Tantamount'ların kızı, Walter'ın diğer sevgilisi. Daha önce şimdi ölmüş olan Henry Tantamount adlı bir akrabasıyla evli olduğunu öğrendiğimiz Lucy, pervasız özgürlüğü ve zevk için yaşama, anın tadını çıkarma özellikleriyle ön plana çıkmaktadır. Lady Edward Tantamount (Hilda) ve Lord Edward aristokrat ve zengin bir aile, Lucy'nin anne babası. Lord, yetmiş yaşında ama hâlâ bir çocuk gibi, Lady ise başkalarına aldırış etmeyen sürekli yüksek sesle ve alaycı bir tavırla konuşan, aslında pek sevilmeyen birisidir. Lady zengin olduğu için ve verdiği partiler sayesinde etrafında insanların olduğu bir kişidir. John Bidlake, Walter'ın ve Elinor'un babası, ressam, Hilda'nın beş yıllık evliyken ilişki yaşadığı kişi ve daha birçok genç kızla birlikte olmuş birisi. Janet Bidlake, John Bidlake'in zaman zaman ayrı yaşadığı üçüncü eşi Elinor ve Walter'ın annesi. Sidney Quarles Philip Quarles'in babası. Geofrey adlı diğer oğlunu savaşta kaybetmiş, para işlerinden anlamayan bir mirasyedi. Parasının çoğunu hiç anlamadığı işlere yatırarak kaybetmiş, kalan kısmı da kaybetmeden eşi olaya el koyarak bu tehlikeyi önlemiş. Ama onun başarısızlığını dile getirerek değil de uğraşması gereken diğer işleri olduğuna ikna ederek yapmıştır. Çünkü Sidney hiç bitmeyen aslında hiç de başlamadığı, sürekli olarak yazmak için kaynak topladığını söylediği politika ile ilgili bir kitap yazdığını söylemekte, kendisini siyaset yazarı olarak görmektedir. Sidney Quarles bir baba olarak da başarısız olmuş bir kişidir. Rachel Quarles, daha yirmisine bile gelmeden gelecek vaat eden, atletik yapılı, üniversiteyi yeni bitirmiş Sidney ile evlenmiştir. Fakat daha sonra onun ahlâksızlıkları, başarısızlıkları ve seks düşkünlüğü karşısında çareyi Hıristiyanlığa sığınmakta bulmuş, Philip Quarles'ın annesi. Mark Rampion duygu ve düşünceleri bağdaşan, belli prensipleri olan ve onlara bağlı olarak yaşayan olumlu, dengeli bir kişilik örneğidir. Yunan kültürü, William Blake ve Whitman hayranı. Mark'ın olumsuz yönü ise annesinin püritan görüşleriyle sürekli fiziksel ve içgüdüsel arzularını baskılayarak yetiştirilmiş olduğu için annesine olan sevgisinin bazen nefrete dönüşmesidir. Ama Mark yıllarını alsa da bunun üstesinden gelmeyi başaran birisidir. Mary Rampion zengin sınıftan gelen fakat ailesini dinlemeyerek aşağı tabakadan da olsa Mark'ın sanatçı kişiliğini ön planda tutarak onunla evlenen kişi. Everard Webley, Britanyalı Hür Adamlar adlı ve özgür girişim yanlısı politik grubun kurucudur. Elinor'a âşık olup evli de olsa onunla birlikte olmak isteyen ve Elinor'u Philip'de olmayan özellikleri ile bir erkek olarak etkileyen birisidir. Fakat Elinor'un tam onunla beraber olmayı kabul etmesinden hemen sonra ilk buluşmalarından hemen önce Maurice Spandrell tarafından öldürülür. Spandrell ikinci eşi olarak General Knoyle ile evlenen Mrs. 
Knoyle'un oğludur ve rezil bir yaşam sürmektedir. Illidge aşağı tabakadan gelen fakat eğitimi sayesinde zenginler sınıfına giren ama daima bunun bilincinde olarak yaşayan birisi olup, her ne kadar zengin sınıftan arkadaşları olsa da zenginlerden aslında nefret eden birisidir. Onun zenginler olan nefreti ve kini, Webley'i öldürmesinde Spandrell'a suç ortaklığı yapmasına neden olmuştur; çünkü Webley'nin özgür girişimi destekleyen politikasına ancak böyle karşı durabileceğini sanmıştır. Ethel Cobbett, Denis Burlap'ın iki yıl önce ölen eşi Susan'ın arkadaşı olup, onun ölümünden duyduğu üzüntüyü dile getirmek üzere Burlap ile tanışmış olan bir bayandır. Daha sonra Burlap onun kendini teselli etme olayını kendi lehine çevirerek onunla aşk ilişkisi yaşamak ister fakat Miss Cobbettt erdemli ve prensipleri olan bir kadın olduğu için ölen arkadaşının eşiyle böyle bir ilişki yaşamak istemez ama yaklaşık on sekiz ay kadar Edebiyat Dünyas/nda Burlap'ın sekreterliğini yapar. Kendisiyle o tür bir ilişki yaşamayan Miss Cobbett'i sekreter ve makale yazarı olarak tutmak istemeyen Burlap, işten çıkması için onu her türlü kötü muameleye maruz bırakır. Beatrice Gilray, önce Burlap'ın dergisinde çalışmaya başlayan daha sonra sevgilisi olan kadın.

Huxley'nin romanda en belirgin özelliklerini komikleştirerek çizdiği yani karikatürleştirdiği roman kişileri de vardır. Örneğin, Beatrice Gilray, Molly D'Exergillod, Mrs. Betterton, Carling, Sita Ram, Cuthbert Arkwright, Willie Weaver ve Peter Slipe gibi. Romanda ikincil derecede önemli olan fakat karikatürleştirilmeden verilen karakterler de vardır. Bunlardan bazıları şunlardır: Polly Logan ve annesi, General Knoyle, George, Bayan Felpham, Hugo Brockle, Ethell Cobbett, Miss Fulkes, küçük Phil, Gladys Helmsley, Mrs. Goffer ve Miss Hignett. Hemen hatırlatmamız gerekir ki bu karakterler de romanın çok sesli olmasını sağlayan ve onun diyalojizmine katkıda bulunan karakterlerdir; çünkü bunlar romanda az gözükseler bile ya kendilerine özgü bir ideolojileri ya da diğerlerinden farklı ve bağımsız sesleri olduğu gözlenmektedir. Örneğin bunlardan Hindistan parlamenteri Mr. Sita Ram'in sesi Hindistan'ın bağımsızığını savunan, İngiltere'yi sömürgeci olarak gören, adalet isteyen bir sestir (Huxley, 1992, s. 118) ama romanda çok yer tutmadığı için onu ana karakterlerden birisi sayamayız. Diğer bir roman kişisi gençliğinde John Bidlake'e modellik yapmış ve aynı zamanda onunla ilişki yaşamış Mary Betterton'ın da kendine özgü bir sesi vardır ama onu romanda sadece Tantamount'ların partisinde duyarız.

Huxley daha önce de bahsettiğimiz mektupta, romancı olarak amacının "sadece birçok farkıı bireysel bakış açlarıyla değil, bilimsel, duygusal, ekonomik, politik ve estetik gibi farklı görünümler altında yaşamdan bir bölüm göstermek" (Smith, 1969, s. 279) olduğunu da vurgulamıştır. Huxley aynı zamanda romanında disiplinler arası ilişkileri de araştırmakta ve bunların insan deneyimlerine olan yaklaşımlarını göstermektedir. Yazar-anlatıı olarak Huxley roman boyunca değişik bakış açılarını vermekte ve olaylara ve kavramlara farkı yorumlar getirmektedir. Bu da doğal olarak romanın polifonik özelliğine katkıda bulunmaktadır. Örneğin, zaman kavramına ilişkin iki değişik görüşü, Isaac Newton ile Aristo'nun görüşlerini mizahi bir şekilde aynı paragraf içinde şöyle vermektedir:

Beatrice Gilray, pembe ipekten bir gömleğin söküklerini dikiyordu. [...] Beatrice dikiyor, saat tıkır tıkır işliyordu. Isaac Newton'a göre, sonsuz geçmişi sonsuz 
gelecekten ayıran devinimli saniye, önüne geçilmez bir hızla ilerliyordu zaman boyutu içinde. Aristo'ya bakılacak olursa da, gerçekleşebilecek olanlar, her saniye gerçekleşiyor; ve şu an yaşadığımız an, hiç kıpırdamadan yerinde duruyor, sonu gelmeyen bir makarna parçasını boyuna yutan bir adam gibi, geleceği içine çekiyordu. Beatrice ara sıra esniyor böylece gerçekleşebilecek bir esnemeyi, bir gerçeğe dönüştürüyordu (Huxley, 1992, s. 206).

Anlatıcı Marjorie'nin hamilelik durumunu hemen bilimsel bir gözlük takarak yorumlar; embriyonun anne karnındaki gelişimini sanki mikroskopla bakıyormuş̧̧asına anlatır: "Altı ay sonra çocuğu dünyaya gelecekti. İlkin tek bir göze, sonra bir göze takımı, küçük bir doku torbası, bir çeşit solucan olan; derken solungaçı bir balığa benzeyen bir şey, Marjorie'nin dölyatağında kımıldıyordu". Sonra anlatıcı bu bakış açısından hemen felsefi bir bakış açısıyla yorumuna devam eder: " günün birinde bir insan olacaktı - dert çeken, haz duyan, seven, nefret eden, düşünen, anımsayan, hayal kuran, yetişkin bir insan olacaktı. [...] yıldızlara bakacak, müzik dinleyecek, şiir okuyacaktı." Anlatıcı bir bakış açısından diğerine geçişler yaparak aynı paragraf içinde Marjorie'nin psikolojisine ilişkin bir yorum da getirmektedir: "Çirkin, yorgun, hasta bir hali vardı Marjorie'nin. [...] hastalığının ve yorgunluğunun farkındaydı Marjorie. Ona kalırsa, bitkinlik, çirkinlik, geleceği için sürekli bir kaygı, kafasında bir dert, bedeninde bir rahatsızlıktan başka bir şey değildi bu giz" (Huxley, 1992, s. 15). Anlatıc r romanın ilk sayfasında okuyucuya Marjorie'yi tanıtırken de moral bir bakış açısı geliştirmekte, daha doğrusu toplumun ahlâki değer yargılarını yansıtan bir bakış açısıyla okuyucuyu aydınlatmaktadır: "[Marjorie] Walter'ın karısı olmadığı için o toplantılara çağrılmazdı. Walter Bidlake ile yaşamak için kocasından ayrılmışı. Hıristiyanlara özgü ahlâk kaygıları olan [...] karısından ö̧ almak isteyen Carling, Marjorie'yi boşamaya yanaşmadı" (Huxley, 1992:13-14).

Huxley romanda anlatıcısına okurların diğer romanlarda pek sık karşılaşamayacağı bir bakış açısı da sağlar: Huxley zooloji ve botanik bilimlerinin insana sağladığı bakış açılarını da romanında bolca kullanmışıı.* Anlatıcı, Mark Rampion dışında hemen hemen her karakteri ya bir hayvana ya da bir bitkiye benzeterek betimler ve roman kişilerinin bazı özelliklerini hayvanlar veya bitkilerin bazı özelliklerinden yola çıkarak verir. Örneğin, Lady Edward'ın "kartallara özgü bir güzelliği" (Huxley, 1992, s. 66) olduğunu belirtir. Bunu bazen de Polly'nin Bayan Betterton'ı file benzetmesi durumunda olduğu gibi bir karaktere yaptıır. Polly "Mrs. Betterton gerçekten file benziyor, [...] Burnu bir hortuma benziyor. [...] Kesilmiş bir hortuma benziyor burnu. Kadın bebekken, ısırıp koparmışlar bu hortumu" der (Huxley, 1992, s. 234). Polly, Hugo Brockle ile

\footnotetext{
Huxley'nin tüm roman boyunca hayvanlarla karakterleri arasındaki yarattığı benzetmelerin detaylı bir analizi için bkz. Sanford A. Marovitz, "Aldous Huxley's Intellectual Zoo", Philological Quarterly, Cilt. 48, 1969, ss.495-507; ayrıca bknz. Jerome Meckier, "Quarles among the Monkeys: Huxley's Zoological Novels", Bloom's Modern Critical Views: Aldous Huxley. (Harold Bloom, Ed.) 2010, ss. 59-76.
} 
tartışmasında zengin orta sınıfı yoksul iş̧̧i sınıfının sırtından geçindiğini için "bir köpeğin sırtındaki pireler"e benzetir (Huxley, 1992, s. 85). Başka bir yerde ise Polly'nin arkadaşı Norah, Lord Edward'ın asistanı Illidge'den bahsederken "havuca benzeyen o küçük adama ne buyrulur?" (Huxley, 1992, s. 64) diye sorar. Elinor yüzü ciddileşen kocası Philip'i ise develere benzetir: "Öfkeden fazla üzüntü gösterdiğin zaman yüzün öyle komik oluyor ki! Hani Bikaner'de gördüğümüz develer vardı ya? Son derece üzgün bir insan yüzü takınmıştı onlar da" (Huxley, 1992, s. 309). Romanın başka bir sahnesinde ise Elinor Philip'e şöyle der: "[S]en, insanlık açısından, insanüstü bir maymun gibisin [...] Aranızdaki tek fark şu: Onlar duygularının ve içgüdülerinin yardımıyla, düşüncelerini yüceltmeye çalışırlar. Oysa sen kafanın yardımıyla duygularını alçaltmaya çalışıyorsun" (Huxley, 1992, s. 129). Lucy, Walter'ın kendine bağı oluşundan hoşlanmakla birlikte onu bir köpeğe, hem de dövülmüş bir köpeğe benzetir: "neden dövülmüş bir köpek hali vardı onda? O kadar miskindi ki! Aman ne aptal şey!" (Huxley, 1992, s. 150) Eşinin başka bir kadınla birlikte olduğunu Mr. Quarles'ın bir konu hakkında çok fazla konuşmasından anlayan Mrs. Quarles onu "hareketlerini gizlemek için çevresine mürekkep saçan" avlanan bir mürekkep balı̆ına benzetir "Sidney de hareketlerini gizlemek için konuşuyor" diye düşünür (Huxley, 1992, ss. 422-423).

Serbest dolaylı aktarım metodunun kullanılmadığı yerlerde, yani anlatıının karakterleri betimlediği ve olayları hikâye ettiği zaman sesi ve yorumu sürekli olarak duyulmaktadır. Ancak bu anlatım tarzının romanın polifonik yapısını bozduğu söylenemez tam tersine romanın diyalojizmine katkıda bulunmaktadır. Çünkü romandaki anlatıının da olaylara ve kişilere olan yaklaşımıyla kendisine özgü, kendi ideolojisi doğrultusunda bir bakış açısı veya bakış açıları geliştirdiği gözlenmektedir. Anlatıcının entelektüel bilgisinden dolayı yorumlarında zaman zaman olaylara değişik açılardan bakabilen birisi olduğu sezilmektedir. Dolayısıyla o da romanda karakterlerden ayrı bir ses olarak durmaktadır. Sanford Marovitz (2013) her ne kadar hem karakterlerin hem de anlatıcının farklı sesleri olmasını romanın polifonik yapısıyla ilişkilendirmese de bu özelliğe değinmektedir:

Farklı şekilde bireyselleşmiş karakterler bu farklılıklarını, düşünceler sanki bir kez kelimelere döküldükten bir süre sonra beklenildiği üzere ilgili davranışlarla ortaya çıkacak şekilde düşünce ve kelimelerle olduğu kadar davranışla da resmetmektedirler. Dahası onlar arasındaki farklılıklar düşünce, konuşma ve davranışla ilgili olduğu kadar ahlâki durumla da ilgilidir. Bu bakımdan da Ses Sese Karşı karakterleri sadece tek bir özelliklerini vurgulama yoluyla bireyselleştirerek seslerini veren geleneksel düşünce romanının ötesine geçmektedir ve özellikle Huxley'in daha önceki romanlarındaki durum, birçoğu, yazarın genellikle komik hayvan imgeleriyle resmederek betimlediği, tuhaflıkları olan karakterlerin olmasıdır. [...] aynı aracı romanı çoğunlukla sınılayan kötümserlik ve hatta şiddete rağmen romana komik bir hava vermek üzere yeterince sıklıkla Ses Sese Karş/da kullanmıştır (s. 6).

Ses Sese Karş/da bakış açılarının çokluğu farklı karakterlerin diğer karakterler hakkındaki görüşlerinin verilmesiyle de sağlanmaktadır. Örneğin, Molly D’Exergillod, Elinor'u kendi bakış açısı ile şu şekilde görmektedir: "Philip 
Quarles'ın karısı, bir perinin tam karşıtı. Ne bir cini andırıyor, ne bilgili, ne de ayrıca akıllı." Molly, Elinor'u oldukça küçümseyerek, gülümsedi: "Philip gibi bir erkek onu zaman zaman yetersiz bulsa gerek" (Huxley, 1992, s. 145). Molly, Elinor'un, kocasını ve Molly'i birazcık yakınlaştırıp duygusal yönünü arttırma çabasında olduğunu anlayamayarak Elinor'u aptal bir kadın gibi görür: "Elinor öyle aptaldı ki, Philip'in kafa bakımından dengi olan, eşit koşullar içinde konuşabileceği bir kadına ergeç kapılacağını bile anlayamamıştı. Philip ile Molly'i bir araya getirince, kocasının nasıl içi titrediğini sezemeyecek kadar aptaldı; kıskançlık duyamayacak kadar aptaldı" (Huxley, 1992, s. 146). Aynı şekilde Lucy Tantamount önce Illidge'nin bakış açısıyla okuyucuya tanıtılmakta daha sonra ise Elinor, Rampion ve sonrasında da Molly'nin bakış açılarılarıyla tanıtılmaktadır. Illidge kapitalist dünyanın zenginleştirdiklerine kin ve öfke ile yaklaştığı için Lucy'yi "kokuşmuş iğrenç şey" olarak görür ve devam eder: "Şu sevimli uygarlığımızın kusursuz bir çiçeği! Yabansı bir yaratığın ya da bir hayvanın zarif ve güzel kokulu bir taklidi bu kadın! İşte, çoğu insan açısından paralı olmanın, boş zamanı olmanın mantıklı sonucu" (Huxley, 1992, s. 94). Webleyn'in aşk çağrısına cevap veremeyen ve Lucy gibi özgür olamayan Elinor'un gözünde ise Lucy diğer kadınlara hiç benzemeyen üstün bir kadındır. Elinor, "Lucy'nin çiçekten çiçeğe konmasını seviyorum [...] kendisi için eğlenceden başka bir şey değil bu. Gerçekten biraz kıskanıyorum onu. Keşke ben de bir peri olsam, havalarda uçabilsem" (Huxley, 1992, s. 147), ve "yaradılışı açısından erkek gibi bir kadındır Lucy. Erkekler gelip geçici serüvenlerden haz alabilirler. [...] Erkeklere özgü bir bağımsızlık vardır onda. Cinsel isteklerini benliğinin öteki yanlarından ayırabilir" der (Huxley, 1992, s. 465). Duygu olmayınca sanatın da olamayacağını savunan Denis Burlap, Philip Quarles için "düzenbazın biri, duygularla hokkabazlık ve dolandırıcılık yapan" (Huxley, 1992, s. 315) birisidir. Aynı şekilde Mary Rampion da Burlap’ın Mark'ı sömüren bir asalak olduğu görüşündedir çünkü Burlap Mark'ın yaptığı resim ve yazdığı şiirleri çok ucuza alıp dergisinde yayınlamakta ve Mark'ın sırtından para kazanmaktadır; oysa Mark kendini sanatına adamış ve iki çocuklu, ailesini güçlükle geçindiren birisidir. Mary Mark'a Burlap hakkında şöyle der: "Ruh açısından tam bir sülük bu adam. Senin kanını emmesine neden göz yumuyorsun?" (Huxley, 1992, s. 331) Philip, Burlap'ın yazılarını ve yaşamını tiksintiyle karşılar. "Manş denizini geçerken insanın midesi bulanır ya, o yazılar da duygu alanında Manş denizini geçmek gibi bir şeydi... Burlap'ın yaşantısı da ne pis, ne vıcık vıcık" diye düşünür (Huxley, 1992, s. 316). Görüldüğü gibi Ses Sese Karşı'da karakterler her zaman saf bir ses, özerk bir söylem olarak karşımıza çıkmaktadır. Hepsinin dünyaya, yaşama, diğer insanlara ve görüşlere yönelik belirli bakış açıları vardır ve bunları daima diyalojik bir düzlemde dile getirmektedirler.

Polifonik bir roman olarak Ses Sese Karşı diyalojik bir söylemdir çünkü romanın büyük bir kısmı diyalog ve konuşmalardan oluşmakta, monologlarda bile bu diğeriyle konuşma özelliği devam etmektedir; söze anlam kazandırma edimi (hem diyalog halindeki karakterler hem de okuyucu için) bu diyalojik düzlemde gerçekleşmektedir. Ama yine de sürekli olarak diyaloglardan anlam çıkarma gayreti içinde olan polifonik roman okuyucusu, tüm fikir, görüş ve anlayışların canlı bir biçimde diyalog içinde somutlaştığı diyalojik düzlemde tek bir kesin 
anlama ulaşamaz. Bu düzlemde sesler birbirinden bağımsız ama yine de bir aradadır. Polifonik bir roman yazarı olarak Huxley her şeyi bir arada, yan yana ve karşılıklı etkileşim halinde vermektedir. Karakterler sürekli diyalog halinde hatta anlatıının söze karıştığı yerlerde bile serbest dolaylı anlatım tekniği ile karakterlerin diyalogları devam etmektedir. Romanda özellikle yazar "Philip Quarles'in not defterinden" bölümü ile Lucy'nin mektuplarının olduğu bölümlerde görüldüğü gibi bazen karakterlerin sesleri tamamen özgür sesler olarak verilmektedir. Burada anlatıcının romandaki konumuna tekrar değinecek olursak öncelikle anlatııının sesinin ve bakış açısının karakterlerin seslerine ve bakış açılarına baskın olmadığını söyleyebiliriz. Anlatııının söylemi tek-vurgulu bir şekilde karakter(ler)in söylemi ile kaynaşmamakta, kendisi ya alaycı, ironik ya da polemik içeren bir vurgu geliştirmektedir. Diğer önemli nokta ise özgül dünya görüşleri olan diğer sesler içinde yazar-anlatıının sesinin de özerk bir ses olarak duyulmasıdır. Bazen ironi bazen benzetmeler yoluyla ideolojilere, ahlâki veya sosyal değer yargılarına yahut politikalara, davranış şekillerine veya huy/mizaç özelliklerine eleştirel bir gözle bakabilen özerk başka bir ses olarak romanda gözükmektedir. Bu bağlamda anlatııının kuru bir bilgilendirici veya tanımlayıcı bir söylem geliştirmediği, kendine özgü, karakterlerinkinden farklı bir ses olarak duyulduğunu söyleyebiliriz. Romanın polifonisi içinde anlatıcının sesi de diğer sesler gibi son sözü söyleyen ses değildir. Zaten polifonik bir romanda söylenecek bir son söz de yoktur. Burada romanda anlatııının ironik ve eleştirel sesini duyduğumuz birkaç örnek verebiliriz: Anlatıcı Lucy'i betimlerken onun "kollarının ve omuzlarının beyazlığını" tamamiyle ortaya çıkaran siyah bir elbise giydiğini söyler. Şu ifade ile devam eder: "Henry Tantamount öleli iki yılı geçmişti. (Lucy, pek yakın olmayan bir akrabasıyla evlenmişti.) Ne var ki, karalar ona ayrıca yakışığı için, Lucy, özellikle geceleri, hâlâ yas tutardı" (Huxley, 1992:76). Lucy'nin partilerde siyahlara bürünmesinin yas tutması ile bir ilişkisi olmadığını, ayrıca cinsel özgürlüğüne düşkün bir kadın olduğunu hem anlatıcı hem de okuyucu bildiği için anlatııının ifadesinin oldukça ironik olduğu açıktır. Romanın başka bir yerinde ise anlatıcı yaşlı Sidney Quarles'ın seks düşkünlüğünü şöyle dile getirmektedir: "Mr. Quarles'ı Londra'ya getiren şey, onun [Gladys'in] yüzü değildi; bir birey olarak Gladys Helmsley değildi. Mr. Quarles'ı Londra'ya getiren şey, Gladys'in erkek cinsinden olmayıp da kadın cinsinden oluşuydu. Mr. Quarles, yapmacık bir dil kullanarak, "Gladys'in biçimi," derdi buna" (Huxley, 1992, s. 425). Burada okur Quarles'ın Londra'daki kütüphanelerde, yazacağı siyasi kitap için malzeme araştırdığını bahane ederek birkaç günlüğüne evden ayrıldığını bildiği için anlatıcının bu sözlerini gülümseme ile karşılar. Bu örnekte ayrıca belirtmemiz gereken bir şey daha var ki o da anlatıcının söylemine Mr. Qurales'ın söyleminin yansıması nedeniyle anlatıının söyleminin diyalojik bir yapısı olduğudur. Anlatıc ressam John Bidlake'in gençlik yıllarındaki halinden bahsederken ise şöyle söyler: "Yakışıklı, iri yarı, coşkun, kaygısız bir adamdı; çok güler, çok çalışır, çok yer, çok içer ve birçok kızı kızlı̆ından ederdi." Fakat hemen belirtmek gerekir ki burada anlatııını bu eleştirel yaklaşımına karşılık Bidlake'in kendi sesi duyulur ve anlatıcının sesi ile çatışır: "Resim cinsel yaşantımın bölümlerinden biridir" der Bidlake ve devam eder: "Bir bedeni, elleriyle, dudaklarıla kendi bedeniyle ezbere bilmeyen adam, çılak bir insan resmi 
yapamaz. Ben sanatımı ciddiye alırım. Hazırlayıcı nitelikteki incelemelerimi hiç savsaklamam" (Huxley, 1992, s. 42). Romanın örnek verdiğimiz bu sahnesi polifonik bir romanda anlatııının kendi bakış açısını karakterin bilincine yansıtması sonucu karakterin, anlatıcının bakış açısına karşılık vermesine güzel bir örnek oluşturmaktadır. Burada yazar-anlatıı karakter karşısında diyalojik bir konumda bulunmakta, sesine karakterin sesi ile karşıılık bulmaktadır. Yazar ve karakterin farklı görüşleri diyalojik olarak kesişmekte ve çakışmakta; dolayısıyla yazarın görüşü tek ve değişmez gerçek olmaktan çıkmaktadır. Bir başka örnekte ise yazar-anlatıının sesi rezillikleri eleştiren ahlâk ve erdem sahibi birisinin sesi olarak duyulmaktadır. Anlatıcı, babasının ölümünden sonra annesi ile daha da yakınlaşan ve annesini çok seven fakat annesinin ikinci evliliği ile sarsılan ve ondan öç almak istercesine rezilce bir yaşam süren, çalışmaksızın, annesinden aldığı para ile geçinen Maurice Spandrell'in bu yaşam tarzını yorumlamaktadır:

Annesinin ikinci evliliğinden sonra, Spandrell [...] benliğinin en kötü yanlarını bile bile geliştirmişti. [...] Annesinden de, eskiden aptalcasına mutlu ve iyi olduğu için kendinden de öç alıyordu böylece [...] Gidebileceği bir cehennem olduğun u umuyor; bu cehennemin varlığına inanamadığı için üzülüyordu [...] ahlâk açısından düşkün yaşantısının ilk başladığı günler, kötü bir şey, yanlış bir şey yaptığını bilmek, onu sevindirmiş, hattâ heyacanlandırmıştı. [...] Ahlâksızca yaşamayı huy edinenlerin çoğu, böyle yaşamaktan hoşlandıkları için değil, böyle yaşamadıkları zaman rahatları kaçtığı için bu tür bir yaşantıyı sürdürürler. [...] Kadına, içkiye, afyon yutmaya, cinsel haz duymak için ya kamçıyla dayak yemeye ya da dayak atmaya alışık olan adam, bunlarsız yaşamayı, susuz, ekmeksiz yaşamak kadar güç bulur. [...] Aslında çok kötü oldukları için onlara ilkin heyecan veren davranışlar, birkaç kez tekrarlandıktan sonra, ahlâk açısından ne iyi sayılır artık ne de kötü. [...] Ne var ki bunlar artık olağan sayıldığı için ahlâk açısından da bir kötülükleri kalmaz (Huxley, 1992, ss. 349350).

Spandrell'in durumunu da pek farklı görmeyen anlatıcı onda artık alışkanlık haline gelmiş olan rezilliklerin ona haz vermediğini bu yüzden de kötü bir şey yaptığı inancını kaybeden Spandrell'in "kendini ahlâksızlığın inceliklerine" verdiğini belirtmektedir. Anlatıcının bakış açısına göre böyle insanlar "kafa açısından en uygar, en ince, en çapraşık insanlardır" ve bunlar

Çesitli kepazelikler yaparak, kendi kendilerine eziyetten haz alıp fuhuşa düşerek, yabancılarla gelişigüzel ve nerdeyse hayvancasına çiftleşerek, kendilerinden aşağı bir tabakadan gelen kaba saba cahil insanlarla cinsel ilişkilere girerek, kendi kendilerini rezil etmeye can atarlar. [...] Artık Spandrell'e gerçekten heyecan veren bir tek ahlâksızlık vardı: Genç kızları baştan çıkarmak (Huxley, 1992, s. 351).

Anlatıcı Spandrell'in bu ahlâksız davranışlarının ardındaki psikolojik durumu da yorumlamaktadır:

Bu merak, [...] Spandrell'in cinsel yaşantıya karşı duyduğu o garip, o hınç dolu nefretten kaynaklanırdı. [...] Böylece fazlasıyla sevdiği, bu yüzden de nefret ettiği kadın soyunun suçsuz kızlarına cinsel tutkunun hazlarını tattırmakla, onları küçük düşürdüğünü sanıyor, bundan ayrıca sevinç duyuyordu (Huxley, 1992, ss. 351-352). 
Romanda yazarın konumu ve söylemi ile ilgili olarak şu noktayı vurgulamak gerekir: Yazar-anlatıının sesinde başka seslerin de tınıları duyulmakta, başka bilinçlerden de yansımalar görülmektedir. Örneğin Tantamount'ların partisinde Illidge'in, Webley konusundaki düşünceleri anlatıının sözlerinde dolaysız olarak yansır, anlatıının düşünceleri ise romanda parantez içindedir:

Illidge, "tenekeden yapılmış bir Mussolini," diyordu kendi kendine. "Ne mal olduğu halinden belli." (Illidge, uzun boylu ve yakışıkı olan, seçkin bir kişiliği varmış izlenimi veren her insana karşı kişisel bir kin duyardı. Kendi ufak tefekti; çok zeki bir sokak çocuğuna benzerdi.) "Koca enayi!" diyordu içinden (Huxley, 1992, s. 72).

Romanın yazar-anlatııının sesinin duyulduğu birçok yerinde, anlatıının konuşmasında serbest dolaylı anlatımın parçalarının araya girdiği görülmekte ve anlatıının kendi konuşmasından diğerlerinin konuşmalarına ince geçişler sözkonusudur. Bunu romandan bazı bölümlerle örneklerken (roman boyunca çok sayıda örnek bulunabilir) yazarın konuşmalarını olduğu gibi bırakıp serbest dolaylı anlatımla verilen kısımları italik olarak vermek geçişleri daha net olarak gösterecektir. Diyalog halindeki Everard ile Hugo'nun direkt konuşmaları romanda olduğu haliyle, tırnak içinde verilmektedir:

Kapıya vuruldu. Hugo Brockle içeri girdi. Everard, önce saatine, sonra da Hugo'ya baktı. Sanki gözdağı veriyordu yüzüyle.

İnsanın ödünü koparan, durgun bir sesle sordu: "Niçin bu kadar geç kaldın?"

Hugo kızardı: "Saat kaç olduğunun farkında değildim."

Söylediği tamamen doğruydu. Öğle yemeğini yirmi mil uzakta, kırlarda oturan Upwich'lerin evinde yemişti. Polly Logan, o evde konuktu. Yemekten sonra, yaş/ı Upwich ile ötekiler, parktaki özel golf alanında oynamaya gitmişlerdi. Polly golf oynamıyordu. Genç kızı gezmeye götürmüş̧ü, ırmağın kıyısındaki korulara. Saatin kaç olduğunun nereden farkına varabilirdi Hugo?

"Özür dilerim," dedi.

Everard Webley, "elbette özür dileyeceksin," derken, sessizliğinin altında gizlenen öfke açığa çıkıverdi (Huxley, 1992, s. 480).

Romandan alınan aşağıdaki bölümde ise anlatıcı, Everard Webley'den etkilenen Elinor'un evli bir kadın olduğu için Webley ile bir ilişki yaşayamayacağı konusunda kendisiyle çatışmasını okura şöyle aktarır: (Burada da yine Elinor'un söyleminin anlatıcının söyleminde duyulan yansımalarını, yani serbest dolaylı anlatımla verilen kısımları italik olarak yazmak yerinde olacaktır. Elinor'un dolaysız konuşmaları ise romanda olduğu gibi tırnak işareti içinde bırakılmıştır.)

Elinor, ikide birde kendi kendini yola getirmeye çalışıyor, "saçma! Çocukça ve saçma!" diyordu.

Tutarlı bir yanı yoktu bunun. Bir kırata bindiği, emirler verdiği ve "yaşa!" diye bağıran bir kalabalık onu alkışladığı için, bambaşka bir insan olamazdı Everard. Elinor, onu alaylarından birinin başında gördü diye, değeri artamazdı Everard'ın. Elinor'un böylesine duygulanması saçmaydı, çocukçaydı. Ne çare ki, Elinor duygulanmıştı; bir gerçekti bu. [...] Elinor çok korkmuştu. Görülmedik bir korkuydu bu! Ya Everard kekeler, duraklarsa; ya aptalca ve bayağı bir şey söyler, lafı fazla 
uzatır, dinleyenlerin canını sıkarsa; ya madrabazlık ederse! Derken Everard konuşmaya başlayınca; sesi zorlanmadan, gür ve güçlü yükselince; sahteliğe düşmeden heyecanlandıran, insana dokunan sözlerle, görkemli ama kısa ve keskin tümcelerle söylevi gelişmeye başlayınca, Elinor öyle coşkun bir sevinç, öyle bir kıvanç duymuştu ki! (Huxley, 1992, ss. 545-546)

Bu konuda romandan son bir örnek olarak anlatıcının sesinde Marjorie'nin sesinden tınılar duyulan bölümü vereceğiz. Burada Marjorie'nin, zengin olması ve güzel görünmesinden dolayı Lucy ile ilişkisi olduğunu düşündüğü Walter'a içerlemesi dolaylı olarak duyulmaktadır:

"O kadının satın aldığı giysileri ben de alabilecek durumda olsam!" Chanel, Lanvin... Vogue dergisinin sayfaları gözünün önünde canlandı. [...] "O kadın çekici olduğu için Walter ondan hoşlanıyor. Ama benim de param olsaydı..." Haksızlıktı bu! Walter Marjorie'den çıkarıyordu kendisinin yoksul oluşunu acısını. Marjorie'ye güzel giysiler alabilecek kadar para kazanmamasının acısını, Marjorie çekecekti gene.

Bir de bebek sorunu vardı. Bunun da acısını Marjorie'den çıkarıyordu. Walter'in çocuğuydu bu. Marjorie hep hasta ve yorgun diye, bıkmıştı Walter; artık hoşlanmıyordu ondan. İşte buydu haksızlıkların en büyügüü.

Bir göze çoğalmış, bir kurt biçimini almıştı. Kurt balığa dönüşmüştü; şimdi de balık, memeli bir hayvanın dölütüne dönüşmekteydi. Marjorie hasta ve yorgundu (Huxley, 1992, ss. 240-241).

Burada serbest dolaylı anlatımla verilen cümlelerin Marjorie'nin diyaloğunda yer aldığı biçimiyle hayal edecek olursak (ki bunu daha önceki iki örnekte bulunan serbest dolaylı anlatımla verilen kısımlar için de yapabiliriz) ortaya şöyle bir konuşma çıkacaktır: "Haksızlık bu! Walter benden çıkarıyor kendisinin yoksul oluşunun acısını. Bana güzel giysiler alabilecek kadar para kazanmamasının acısını ben çekeceğim gene. Bir de bebek sorunu var. Bunun acısını da benden çıkarıyor. Walter'ın çocuğu bu. Ben hep hasta ve yorgunum diye bıktı Walter; artık hoşlanmıyor benden. İşte bu haksızlıkların en büyüğü!"

Birinin diyaloğunda başkalarının diyaloğunun seslerinin duyulması Ses Sese Karş/da sadece anlatıcının değil karakterlerin diyalogları için de geçerlidir. Bu da bize Bakhtin'in dilin zaten özde diyalojik olduğu, söylemin hiçbir zaman özgün olamayacağı ve bilincin daima diğer bilinçlerle etkileşim içinde olduğundan tekil olamayacağı görüşlerini hatırlatmaktadır. Polifonik romanın bu özelliğine ilişkin olarak birçok örnek bulabiliriz romandan: Örneğin, Tanrı'ya inanmayan Spandrell'in sözlerinde Mark Rampion'un sesi de duyulur. Romandan alıntılanan aşağıdaki bölümde Rampion'un sesinin tınıları Spandrell'in diyoloğunda tekrar duyulmaktadır:

Spandrell için, Tanrının en güzel şakası, var olmayışıydı. Düpedüz var olmayışı. Ne Tanrı vardı ortada ne de Şeytan. [...] "Tanrı ayrı bir yerde değildir; ne bizim üstümüzde, ne de dışımızdadır." Rampion'un vaktiyle söyledikleri aklına geldi. "Yani Tanrının bizi ilgilendiren, insanlar için önemli olan nitelikleri, ne üstümüzdedir, ne de dışımızda. [...] Yaşamadan yana olan, dünyayla canlı bir ilişki kurmaya yarayan herhangi bir düşüncenin ya da davranışın, hem maddesel hem de ruhsal toplu sonucudur Tanrı. [...] Spandrell, Illidge'e göndereceği kartpostalın adresini yazarken bunları düşündü: "Tanrı yoktu ortada, Şeytan yoktu. Ancak çöp tenekeleri arasında, 
pis bir soytarılığın anısı vardı; [...] Tanrı züppesi..." İşte Rampion böyle derdi Spandrell'e. Var olmayan bir Tanrıyı bulmak için pisliği karıştıyor. Ama hayır, hayır! Tanrı vardı, dışarıdaydı, mutlaktı. Yoksa dualar tutarmıydı hiç? Çünkü dualar tutuyordu. [...] Tanrı vardı ama saklanıyordu. [...] Bizim dışımızda ve üstümüzde olan Tanrıyı, zorla, sürükleye sürükleye çekip içimize almaktı bütün sorun (Huxley, 1992, ss. 677-679).

Bu bölüm aynı zamanda Spandrell'in ikilemini yansıtması açısından polifonik roman karakterlerinin kendi kendileriyle çelişen sesleri olabileceğine de bir örnek oluşturmaktadır. Birinin diyaloğunda diğerinin sesinin duyulmasına örnek oluşturacak romandan başka bir sahne de aşağıda verilmektedir:

Illidge evet der gibi başını eğdi. Spandrell'in bu son sözüyle, Lady Edward'ın Webley ile alay ederken söylediği aklına gelmişti ansızın. "Ölümünden sonra kendi dev boyutlu heykeline karşı nasıl davranılması gerekirse, kendine karşı da öyle davranılmasını istiyor, anlarsınız ya" (Huxley, 1992, s. 626).

Sahneyi biraz açıklamak gerekirse Spandrell ve Illidge, Everard Webley'i öldürdükten sonra bir müddet cesede dokunamadıkları için ceset katılaşmış ve neredeyse bir heykel görünümünde boylu boyunca durmaktadır, onu kendi arabasının bagajına koymaya çalışmaktadırlar. "Dev boyutlu heykel" benzetmesini ise ilk önce kimseden çekinmeyen, her şeyi alaya alan Lady Edward kullanmıştır. Verdiği partide hem politik kariyerinden hem de dış görünüşünden dolayı Webley'nin azameti ve ihtişamlı duruşu ile alay etmiştir; bunu Illidge de duymuştur:

O ne enerji! [...] Bu siyaset adamları yok mu - kadın tiyatro oyuncularından bile beter bunlar, kendilerini beğenmek konusunda! [...] Kendi kendisinin heykeli oldu sanki; hayranlık ve minnet dolu bir milletin diktiği, dev boylu heykeline karşı nasıl davranılması gerekirse, kendine karşı da öyle davranılmasını ister (Huxley, 1992, s. 73).

Ses Sese Karş/nın çok sesli dünyası doğal olarak son derece kişiselleşmiş bir dünyadır. Her düşünce bir kişiliğin konumu olarak algılanıp yansıtılmaktadır. Karakterlerin hem dünyaları hem de bilinçleri birbirine kapalı değil aksine açıtır. Yani dünyalar arası ve bilinçler arası bağlantılar vardır. Karakterler kendi içlerine kapalı ve diğerlerine sağır değillerdir. Birbirleri hakkında birçok şey bilir ve birbirlerinde yansırlar. Birbirlerini duyar ve yanıtlarlar, tartışırlar, çelişirler veya uzlaşırlar. Bu da aralarındaki diyalojik ilişkiler aracılığıyla olur. Romanda karakterlerin birbirlerini tanımalarına, birbirleri hakkında birçok şey bilmelerine verilebilecek güzel bir örnek, Mrs. Quarles'ın yazacağı siyasi kitap üzerine araştırma yapmak bahanesiyle Londra'ya sık sık giden Mr. Quarles hakkında bildikleri ve yaptığı yorumlardır:

Mrs. Quarles, kocasının Londra'ya ikinci gidişinden sonra,"acaba Sidney yeni bir kadın mı buldu?" diye meraklanmış, üzülmüştü. Mr. Quarles, Londra'dan üçüncü dönüşünde [...] eski Hintlilerdeki demokrasinin görülmedik çapraşıklığını ileri sürerek, gösteriş yaparcasına oflayıp puflamaya başlayınca; Mrs. Quarles, kocasının 
bir kadın bulduğunu anladı. [...] Vah zavallı Sidney! Kendini bir Machiavelli kadar kurnaz sanıyordu [...]

Mrs. Quarles biraz iğnelercesine sordu: "Kitapları, Londra kitaplığından gönderemezler mi size?"

Sidney başını salladı; çok önemli işler yaparcasına şişinerek, "o çeşit kitaplar ancak British Museum'da bulunur," dedi.

Rachel içini çekti. O kadını akıllı davranıp, hem kendi başını derde sokmaması; hem de Sidney'in başına çorap örecek kadar açıkgöz olmamasıydı tek isteği (Huxley, 1992, ss. 422-423).

Romanda birbiriyle çatışan sesler romanın polifonik yapısına belki de en çok katkı sağlayan öğeler olarak görülebilir çünkü seslerin farkılığı, insanların farklı kanı ve düşüncelerde olduğu, bu farklılıklara rağmen yine de bir arada bulundukları ve bulunmaları gerektiği gerçeğini net bir şekilde yansıtmaktadır. Ayrıca diyalojik düzlemde yer alan bu farklı sesler aracılığıyla hem romandaki kişiler birbirleriyle ve kendileri ile ilgili hem de okuyucu roman kişileri ile ilgili anlamlara ve çözümlemelere ulaşmaktadır. Yani anlam bu farklı seslerin bir arada çınladığı diyaloglar içinde ortaya çıkmaktadır. Bu, roman boyunca yer alan tüm diyaloglar için geçerlidir ancak romandaki karakterler ve aralarındaki diyalogların çokluğu göz önünde bulundurulduğunda burada birkaç örnekle yetinmek yerinde olacaktır: Daha romanın başında iki âşık Marjorie Carling ve Walter Bidlake'in birbirine zıt seslerini duyarız. Marjorie'nin Walter tarafından daha çok sevilme arzusunu dile getirmesine karşılık Walter'ın ondan kurtulmak, serbest kalmak istemesine ilişkin iç dünyasının sesi duyulur (Huxley, 1992, ss. 13-36). Akıl ve sağduyu sembolü Philip Quarles ile onu duygusuz bir insan olarak gören eşi Elinor'un farklı kişilikleri diyalojik düzlemde ortaya çıkmaktadır. Örneğin Elinor'un duygusal yanı araba ile giderlerken şoförün bir köpeği ezmesi sırasındaki diyalogda ortaya çıkmaktadır:

Elinor, otomobilin tam önünden koşarak geçen bir köpeği görünce daldığı düşüncelerden silkindi. Köpek [...] bir saniyecik göründü; [...] sonra karanlıkta yok olup gitti. [...]

Elinor bağırdı:"Ah! Ezil..." [...] "Ezildi bile"

Hintli şoför döndü; sırıtarak ona baktı. [...] Elinor ürperdi: "Zavallı hayvan!"

Philip, "kendi kabahati," dedi. "Önüne baksaydı" (Huxley, 1992, s. 132).

Bu diyalog aynı zamanda Philip'in de kişiliği ile ilgili ipuçları vermektedir. Duygusal yönü zayıf buna karşılık akılcı, her şeyi analitik, bilimsel veya felsefi terimlerle düşünen Philip burada da pek farklı davranmamaktadır. Elinor'un Philip'den yazmasını istediği öykü de Elinor'un duygusal yönünü göstermektedir: "Ama gene de günün birinde, düpedüz ve sade bir öykü yazmanı isterdim: Birbirini seven, evlenen, güçlüklerle karşılaşan, bunları yenen ve sonunda rahata kavuşan genç bir erkekle, genç bir kadının öyküsünü" (Huxley, 1992, s. 311). Modern dünyanın getirilerinden hoşnut, akıl yoluyla yaşamayı tercih eden Philip ile modern, teknolojik, makineleşmiş bir dünyaya tereddütle yaklaşan ve eleştiren bir entelektüel olan Mark Rampion'un kişilikleri, aralarındaki diyalogla açığa çıkmaktadır: 
Philip, [...] "Ama ne çare ki dünyamız bu hale geldikten sonra, artık geri dönülemez, makineler ıskarta edilemez. [...] Sanayileşme yüzünden, dünya nüfusu yüz yıl içinde, iki kat arttı. Eğer sanayileşmekten vazgeçmeye kalkarsanız, başladığınız noktaya geri dönmeniz gerekir. [...]

Rampion, [...] "Sanayide ilerleme, fazla üretim demek, yeni pazarlar elde etmek zorunluluğu demek, uluslararası yarışma demek, savaş demek. Makinelerin gelişmesinin sonucu da, [...] bireylerle ilgisi olmayan makineleşmiş eğlencelerin artması, kişisel atıımların ve yaratıcılığın azalması, kafanın gittikçe ön plana geçmesi, insan yaradılışındaki tüm canlı ve önemli yanların yavaş yavaş soysuzlaşması, can sıkıntısı ve tedirginliğin çoğalması (Huxley, 1992, ss. 483-484).

Edebiyat Dünyası dergisinin yöneticisi Denis Burlap'ın hayata bakışı, en çok inandığı şey kendi sözleriyle verilmektedir. "Yaşamak her şeyden önemliydi eninde sonunda. "Ben yaşamaya inanırım" (Huxley, 1992, s. 332). Burlap'ın Philip'in hatırladığı bir konuşma esnasında ona şöyle tavsiyede bulunduğunu duyarız ki bu aynı zamanda Burlap'ın kişiliğini de açığa vurmaktadır: "[E]ğer yürekten geleni yazmazsan, iyi bir kitap yazamazsın asla" (Huxley, 1992, s. 312). Denis Burlap'ın yaşama hedonist bir yaklaşımı olması, bilimsel bakış açısını sürekli eleştirmesi, parayı çok sevmesi, ruha verdiği dinginlikten dolayı sanata hayran olması gibi özelliklerinin tümü de diyalojik düzlemde ortaya çıkan gerçeklerdir. Romandaki bir başka karakter Lucy'nin Walter'ın duygusal yönüyle çelişen kişiliği Walter'la konuştuğu zaman açığa vurulur:

Lucy alay etti: "Romantik! Romantiksin sen! Aklından geçenlerin tümü öylesine saçma öylesine modası geçmiş ki! [...] aşk, filan, falan! Saçma şeyler bunlar. [...] Bugünün adamı olmaya çalışsana biraz."

"İnsan olmayı yeğlerim ben."

Lucy konuşmasını sürdürdü: "Hızla yaşamak demektir bugünün yaşantısı. Bir araba dolusu ülküyü, romantik tutumları, peşinsıra çekip sürükleyemezsin yaşadığımız çağda. İnsan uçakla yolculuğa çıkarken, ağır eşyalarını geride bırakır. Yavaş yavaş yaşanıldığı sıralarda, o güzelim eski moda ruh iyi bir şeydi. Ama şimdi fazla ağır geliyor ruh. Uçakta yer yok ona" (Huxley, 1992, ss. 328-329).

Sınıf bilincini kavramış ve bunun acısını çeken bir birey olan Illidge'in diyalogları onun zengin sınıfa saldırılarını içerirken bu özelliklerini de açığa çıkarmaktadır. Asistanı olduğu Lord Edward ile bir konuşmasında "toplantılar, müzik, bilim! Bütün bunlar, boş vakti olan insanlar için değişik eğlenceler. Parayı öder, istediğinizi seçersiniz. Asıl sorun, insanın ödeyecek parası olmasında" der (Huxley, 1992, s. 100).

Mark Rampion ve Mary'nin evlenmeden önce arkadaşlıkları sırasındaki diyalogları vasıtasıyla Mary'nin zengin sınıfa ait ama ait olduğu sınıfın insanlarının genel özelliklerini taşımadığını, Mark'ın yoksul ama akıllı, duygulu ve çalışkan bir genç olduğunu öğreniyoruz. Kitabın Mark ve Mary ile aileleri ve arkadaşları arasındaki diyaloglarla dolu olan 9. Bölümü'nde Mary'nin Mark gibi yoksul fakat kişilikli birisi ile evlenmeyi tercih ettiğini Mark'ın da Mary ile evlenmesine rağmen hâlâ zengin sınıf için olumlu şeyler düşünmediğini ve bilim, teknoloji ve uygarlığa olan inancını yitirmiş olduğunu (Huxley, 1992, ss. 171, 482-483) görmekteyiz.

Laboratuvarındaki "asimetrik kurbağa yavruları" ve topraktan fosforun azalması konusuyla politika ve paradan daha fazla ilgilenen bilim adamı Lord 
Edward'ın onu Britanyalı Hür Adamları desteklemesi konusunda ikna etmeye çalışan Webley'e karşı itirazları gerçekten de Lord Edward'ın kişiliği ile tam olarak örtüşmektedir: "Ama benim siyasetle ilgim yok ki!" (Huxley, 1992, s. 95) "Evet ama [...] Ben... ben parayla ilgilenmem" der (Huxley, 1992, s. 96).

Polifonik bir romanda "karakter kendisi hakkında her şeyi bilir, bunları özümsemeye çalışır" (Bakhtin, 2004, s. 104). Ses Sese Karş/da bu öz-bilince sahip olma özelliği kakterlerin çoğunda vardır. Biz burada Everard Webley; Maurice Spandrell, Philip Quarles ve Illidge'in öz-bilincinin diyaloglarında yansımasını göstermekle yetineceğiz: Webley'nin Elinor'la konuşmasında duyulan kendisi hakkındaki söyledikleri onun bir öz-farkındalık süreci içinde olduğunu ve ayrıca kişilik özelliklerini okuyucuya yansıtması açısından önemlidir:

"Kendimi beğendiğimi sanıyorsunuz. Bir bakıma haklısınız galiba. Ama sorun şu ki kendimi beğenmekte haklı olduğumu biliyorum ben; [...] Alçakgönüllülüğün sahtesi, zararlı bir şeydir. 'İnsanın dürüst davranarak ve haklı olarak kendine saygı duyması kadar yaralı bir şey olamaz' der Milton. Yapmak istediklerimi yapabileceğimi de biliyorum. Yüzde yüz güvenim var buna. [...] Ben onların efendisi olacağım. Benim isteğime zorla boyun eğecekler. Bunu yapacak kadar kararlı ve gözüpekim. Çok yakında örgütlenmiş bir gücüm de olacak (Huxley, 1992, s. 444).

Spandrell'ı evliliğe teşvik etmeye çalışan Mary ve Mark Rampion'la Spandrell'ın konuşmalarında kendisi hakkındaki gerçekleri kendisinin açığa vurduğu görülmektedir. Kendi ahlâksızlıklarını ve genç kızları nasıl tuzağa düşürdüğünü yine kendisi anlatmaktadır: "Tanrı bir görev verdi bana: Dişileri, özellikle genç dişileri baştan çıkarmak görevi. Benim işim onları eğitip yanlış yola sürmek" (Huxley, 1992, s. 158). Aynı bağlamda şöyle devam eder:

Mutsuz olanları seçmeli [...] İlkin onlara karşı sevecen, çok sevecen olmalı. Tıpkı bir ağabey gibi, aklı başında ve cinsel namus açısından tertemiz olmalı. 0 zaman sizi gerçekten eşsiz bir insan sanırlar. [...] Öyle bir eğitiyorsunuz ki onları, ara sıra sırtlarını şöyle kardeşçe okşadığınızda ya da bir amca gibi alınlarını şöyle bir öptüğünüzde, ürkmüyorlar artık. [...] Bu arada onları güzel güzel kandırıp, ufak tefek sırlarını öğreniyorsunuz. [...] Sonunda zamanı gelince, onlar iyice evcilleşip korkularını yitirince son perdeyi sahneye koyuyorsunuz. [...] Ortaya kokteyller çıkarırsınız - çok sert kokteyller. [...] Sonra, ayaklarının dibine oturup, tamamiyle platonik bir biçimde, ayak bileklerini okşamaya başlarsınız tatlı tatlı. Kendi elinizin ne yaptığından sanki hiç haberiniz yokmuş gibi! [...] Ama asıl eğlence, bundan sonra, yani onlar metresiniz olduktan sonra başlar. [...] Onların cinsel yeteneklerini geliştirirsiniz. Hep uslu uslu, hep tatlı tatlı ve çok sabırlı davranarak, cinsel tutkunun tüm rezaletlerine alıştııısınız onları. [...] Olanca saflıklarıyla, aklın alamayacağı bir ahlâksızlık düzeyine getirebilirsiniz onları (Huxley, 1992, ss. 189-190).

Philip Quarles'ın içsel hesaplaşması onun kendi benliği hakkındaki düşünceleri yansıtan bir nevi itiraf diyalogu sayılabilir (burada Philip'in kendisi hakkında düşündükleri serbest dolaylı anlatım yoluyla anlatıcı tarafından aktarılmaktadır):

Hiç şaşmadan, dürüstçe kendi benliğine bağlı kalması daha hayırlıydı. Kendi benliğine mi? Ama işte, Philip'in bir türlü çözümlenemeyen sorunlarından biri de bu benlik sorunuydu. [...] Onda öyle bir benimseme yeteneği vardı ki, çoğu zaman 
kendisiyle başkası arasındaki ayrımı görememek tehlikesine düşerdi. [...] Amipler, kendilerine bir av bulunca, ona sarılırlar, onunla bir olurlar, sonra da akıp giderler. Philip Quarles'ın kafa yapısında da, bu amipleri andıran bir şeyler vardı. Onun beyni, ruhsal protoplazmadan yapılmış gibiydi; her yana akabilir, önüne çıkan her şeyi kendi içine alabilir, her girintiye çıkıntıya dolabilir, her kalıba dökülebilirdi. Önüne çıkanları, kendi içine aldıktan, doldurduktan sonra da, başka engellere doğru akabilir; ilk doldurduğu kapları boş ve kupkuru bırakarak, başkalarına dökülebilirdi. [...] candan bağlanacağı benlik neredeydi acaba? [...] kendi benliğinin gizli derinliklerinde, Katolik de olmadığını, çabayla yaşayan bir insan da olmadığını, gizemci de olmadığını, soylu bir vahşi de olmadığını pekâlâ biliyordu (Huxley, 1992, Ss. 312-315).

Bir başka roman kişisi Illidge'in Everard Webley ile diyaloğu onun kendisi hakkındaki düşüncelerinin, bir anlamda onun öz-bilincinin yansımasıdır: "Ama bana metelik vermezlerken, benden on kat daha aptal, berbat bir yazar müsveddesinin paralar kazandığını, pohpohlandığını görmek, çileden çıkarıyor beni zaman zaman" [...] Dış görünüşünden ötürü çok üzülürdü Illidge: Çirkin olduğunu, sıradan bir insana benzediğini bilirdi." Webley'e şöyle söyler: "Gerçek şu ben bir anarşiste benziyorum. [...] Siz talihli adamsınız, biliyor musunuz? Kibar bir baya, hiç olmazsa bir sanatçıya benziyorsunuz. Aşağı sınıftan gelen bir aydına benzemenin ne baş belası bir şey olduğunu bilemezsiniz" (Huxley, 1992, s. 90). Illidge kendisi hakkında diğerlerinin, "tatsız bir adam" de dediğini bilir (Huxley, 1992, s. 101). Illidge, Philip, Spandrell ve Walter ile bir arada olduğu, zenginlerin gittiği kulüpte iken hayranlıkla etrafa bakarak "vay canına! [...] İşte böyle şeyler görünce, aşağı tabakadan geldiğimi öyle bir anlıyorum ki [...] benim burada bulunmam bile garip bir şey, gerçekten olağanüstü bir şey" demesi onun özbilincini yansıtan başka bir örnektir. Çünkü Illidge aslında yoksul bir ailenin çocuğudur; fakat hasta bir çocuğu olan zengin bir ailenin, havasından dolayı onların köyünde oturmaya başlaması ve zengin çocuğun köy öğretmeninden özel dersler alırken Illidge'in de bedava olarak dersleri dinleyip Manchester'deki bir okulda burs kazanması sonucu aldığı eğitim ile şimdiki pozisyonuna ulaştığını biliyoruz (Huxley, 1992, ss. 450-451). Tüm bunlar okura Illidge'nin kendi bakış açısıyla, kendi sesiyle verilmektedir.

Romanda karakterlerin dışsal olarak duyulan konuşmaları ile içsel seslerinin de çelişkili olduğu gözlenmektedir; yani konuşmaları ile zihinlerinden geçen düşünceler arasında tam bir zıtlık söz konusudur. Bu da romanın polifonik yapısına katkıda bulunan bir özelliktir. Burada karakterlerin iç dünyalarının seslerini yazar-anlatıcının serbest dolaylı anlatım tekniğiyle okuyucuya sunduğunu bir kez daha hatırlatalım. Roman boyunca birçok örneğine rastlayabileceğimiz bu özelliğe birkaç örnek vermekle yetineceğiz. Örneğin biraz daha kalması için Walter'ı ikna etmeye çalışan Lucy ile konuşurken Walter'ın çelişen dış ve iç sesini duyarız: Lucy'e "Eve gitmeliyim. [...] Olmaz, olmaz" der ama içindeki ses şöyle der: "Ne var ki Lucy'nin söylediği doğruydu. Marjorie'ye öyle çok çektirmişti ki, bir süre daha kalmakla nasıl olsa daha mutsuz edemezdi onu. Marjorie ortadan kalksa diye düşündü; ölse, çocuğunu düşürse, kanı zehirlense..." (Huxley, 1992, s. 242) Yaşlı Sidney Quarles'ın metresi Gladys'e mektup dikte ettirdiği zamanki diyalogları boyunca hem onun hem de Gladys'in iç seslerini sıkça duyarız: 
[Quarles] yalnız parası pulu olan kibar bir adam değil, aynı zamanda büyük bir düşünür olduğunu belirtmek için, "bilemezsiniz siz," diye söze başladı, "bunlardan çok daha ciddi ve önemli sorunları düşünen bir adam için, bu ıvır zıvır işlerin ne denli sinir bozucu olduğunu bilemezsiniz siz."

Gladys, "öyledir herhalde," dedi.

"Amma da tuhaf bir adam!" diye düşünüyordu içinden.

Mr. Quarles, "yazınız," diye buyurdu. [...]

Gladys, [...] bileğindeki saate baktı. On ikiyi on geçiyordu. Nerdeyse öğle yemeği vakti gelecekti. Yeni bir saat... Adama aldırtacağı ilk şey işte bu olacaktı. Şimdiki saati öylesine ucuz, öylesine çirkindi ki! Doğru dürüst işlemiyordu üstelik.[...]

Mr. Quarles gözlerini açmadan, "Düşünceler Kitabı için not" dedi. [...] gözlerini açar açmaz, Gladys'in güneşten yanmış ten renkli çoraplarının üst kısmının, bir hayli yukarılarına kadar göründüğünü fark etti. Gözleri çorabın üst kısmına dikili, yazdırmasını sürdürdü. "Ömrüm boyunca bu yersiz [...] acısını çektim, nokta. Biliyorum, virgül, bazı düşünceler, virgül, [...] Mr. Quarles çorabın bittiği yerde teni var diye düşünüyordu. Gürbüz, kıvrak, etini sıkı sıkı saran, yumuşak teni. Okşamak, okşarken, ipek gibi bir tenin, kendi parmak uçlarını okşadığını duymak. Eti bir avuç dolusu lastik gibi sıkmak. Hatta ısırmak (Huxley, 1992, ss. 429-430).

Roman birbirine zıt, çatışan sesleri verirken, her karakterin kendi özerk sesini koruduğu görülmektedir. Örneğin Elinor ve kayınvalidesi Rachel Quarles'ın diyaloglarının duyulduğu sahnelerde ikisinin son derece farklı sesleri olduğu görülürken birinin diğerine taviz vermediği, boyun eğmediği ve diğer sesin boyunduruğuna girmediği gözlenmektedir. Bu karakterler hakkındaki anlamlar bu diyalojik düzlemde ortaya çıkmakta ve okuyucu onların kişiliklerini yine kendi söylemleri aracılığıyla anlamaktadır. Elinor dini duyguları yok denecek seviyede hatta dini ve dindarlığı saçma bulan birisi olarak görünürken, kayınvalidesi son derece dindar birisi olarak gözükmekte ve dolayısıyla bakış açısı da dini düşünceleri aracılığıyla oluşmaktadır. Romanın bir sahnesinde Elinor, Rachel'a Philip'le aralarının iyi olmadığını söylerken, bir anlamda dertleşirken, bir yandan Elinor'un düşünceleri ile kayınvalidesinin düşünceleri arasındaki çatışma dolayısıyla her ikisinin farklı bakış açılarını görülürken öte yandan her ikisinin de dışa vuramadıkları içsel sesleri duyulur:

Mrs. Quarles, "[...] Gerçekten nasıl? Seninle arası nasıl?"

Bir sessizlik oldu. Elinor hafifçe kaşlarını çattı, yere baktı. Sonunda, "benden uzak," dedi. [...] "Şimdi bir de çalışması var. Durum daha da beter bu yüzden. Bir dağın tepesinde bir kale gibi onun çalışması. Bu çalışmanın içine kapanıyor, teslim olmuyor."

Mrs. Quarles, [...] "Belki sonunda kendiliğinden teslim olur." [...]

Elinor içini çekti: "Bana teslim olacağını hiç sanmam. Ben onun bir alışkanlığı oldum artık. Bir alışkanlık olan kişi, ansızın yeni dünyalar açan, görülmedik bir varlığa dönüşemez ki."

Mrs. Quarles başını salladı. Son yıllarda Sidney'e [Mrs. Quarles'ın eşi] yeni dünyalar açan görülmedik varlıkların, insanı şaşırtacak kadar sıradan yaratıklar olduğunu düşündü. Örneğin, mutfak işlerine bakan hizmetçi kız, ya da av koruyucusunun kızı... Sidney nasıl yapabiliyordu bunu? Anlaşılmaz bir işti bu.

Mrs. Quarles'ın sesi neredeyse bir fısıltıydı: "Hiç olmazsa Tanrıya sığınabilsen?" [...] "Tanrıyı hele bir bulabilsen!" 
Acı bir alay vardı Elinor'un gülümsemesinde. Konuşulan konuyla uzaktan yakından hiçbir iliş̧isi olmayan bu çeşit lâflar sinirine dokunurdu.

"Belki daha kolay bir hal çaresi var," diye söze başladı, ama hemen kendini tuttu. "Bunun daha kolayı bir erkek bulmak," diyecekti. [...]

[Mrs. Quarles] "Ne söylüyordun?"

Elinor başını salladı: "Hiç" (Huxley, 1992, ss. 420-422).

Bu diyalojik düzlemde Elinor ve Mrs. Quarles'in sözlerinin birbirini açımladığı da görülmektedir. Sözlerin anlamı hem daha önce söylenen söze hem de diğerinin algılamasına bağlı olarak ortaya çıkmaktadır.

Ses Sese Karşı polifonik bir romanın anlam sabitlikleri içermemesi özelliğini karakterler hakkında değişmez anlamlara ulaşamama, karar verilemezlikleriyle netleştirmektedir. Başka bir deyişle okuyucu tabii ki romanın diyalojik düzleminde karakterlere ilişkin belli anlamlara ulaşmaktadır fakat bu anlamlar ne karakterleri basmakalıp tipler haline getiren özellikler ne de monolojik bir romanda olduğu gibi onları sınırlayan özellikler değildir. Bakhtin (2004) monolojik bir romanda kahramanın kapalı olduğunu, "anlamsal sınırlarının kesin biçimde çizildiğini" belirtir ve "kahraman ne ise odur ve olduğu şeyin sınırları içinde [...] edimde bulunur, deneyimler, düşünür ve bu sınırlar içinde bilinçlidir" der (s. 103). Monolojik romanın aksine polifonik bir romanda, bir karakteri bir özelliği ile tanıyan okura onun daima öyle bir kişilik olacağı garantisi verilmemektedir. Aksine polifonik roman kişisi, kendi karakterinin, tipikliğinin veya mizacının sınırlarını aşabilir; her zaman ani değişikliklerle okuyucuyu şaşırtabilir. Karakterlerin tahmin edilemez oluşu doğal olarak okuyucunun beklentisi dışında gelişen bir dizi olayı da beraberinde getirmektedir. Ses Sese Karş/da özellikle romanın sonuna doğru görülen okurun beklentileri ile çakışan olaylar vardır. Örneğin yıllardır midesinden rahatsız olan yaşlı ve kanser hastası John Bidlake'in öleceğini düşünürken Elinor ve Philip Quarles'ın oğlu, yani Bidlake'in torunu küçük Philip'in menenjitten dolayı aniden ölmesi okurun yaşam ve ölüm hakkında sabit fikirler oluşturmasını engellemektedir. Yaşlı Bidlake'in uzun uzun üzerinde durulan mide rahatsızlığı okuyucuyu da Elinor'unki gibi bir düşünceye itmiştir. Elinor "ama ne de olsa, yaşıdır o," diye düşünür. "Önüne geçilemezdi bunun. Babası fenalaşmış olabilirdi, ama küçük Phil iyileşiyordu; asıl önemli olan da buydu" şeklindeki içsel konuşması duyulur. Bunun hemen sonrasında ise anlatıcı Philip'in öldüğünü söyler: "Çocuğun çırpınmaları çok şiddetli olmuştu; bitkin bedende dayanacak güç kalmamıştı. Odasına varınca, küçük Phil'i ölü buldular" (Huxley, 1992, s. 674). Öte yandan Walter ve Lucy'nin durumlarında bir tahmin edilemezlik söz konusudur. Walter'ın artık elde ettiğini sandığı Lucy, Fransa'da önüne çıkan genç bir İtalyanla birlikte olmuş ve Walter'ı artık istemediğini söylemesi bir yana bu genç ile ilişkisini Walter'a mektubunda anlatmıştır: "Ömrümde ilk kez gördüğüm, kim olduğunu bile bilmediğim bir erkek... Heyecan verici birşey bu. Şu an birbirine tamamiyle yabancı, bir saniye sonra da, iki kişi birbirine ne denli yakın olabilirse o denli yakın olan iki insan" (Huxley, 1992, s. 572). Lucy'nin Walter'la olan ilişkisinde görülmeyen sado-mazoşist eğilimleri bu ilişkisinde görülmektedir ki bu da Lucy hakkında kesin anlamlara ulaştığını sanan okuyucuyu şaşırtmaktadır. Lucy mektubuna şöyle devam eder: 
Takside bana dokunmasına izin vermemiştim. Dişlerini sıkarak, sanki beni öldürecekmiş gibi, üstüme yürüdü. Hıristiyanca bir tutumla gözlerimi kapadım. Kurban olmak insana heyecan veriyor. Canının yanmasına, küçük düşürülmeye, bir paspas gibi kullanılmaya razı olmak... Ne garip! Hoşuma gidiyor. [...] Çok güzel ve yabansı bir hali vardı [...] Hali ne denli yabansı ise, kendi de öyleydi. Isırdığı yer hala geçmedi ensemde (Huxley, 1992, s. 573).

Everard Webley'nin artık aşk çağrısına kulak verdiğini ve birlikte olacağını sandığı Elinor'u beklerken Spandrell tarafından siyasi amaçlı bir cinayete kurban gitmesi romandaki bir başka tahmin edilemez durumdur. Kötülük timsali Spandrell'in, yaşamının çirkinliğine dayanamayarak kendini öldürmesi, ayrıca Spandrell'e suç ortaklığı yapan Illidge'in Everard Webley'nin ölümünün aslında işe yaramadığını, bu suikast ile faşizmin daha da güçlendiğini görerek hayal kırıklığı yaşaması (Huxley, 1992, s. 676) ve Burlap'ın Beatrice Gilray uğruna terk ettiği Ethell Cobbett'in havagazı soluyarak intiharı (Huxley, 1992, s. 693) romandaki diğer beklenmedik durumlardır.

Ses Sese Karş/nın heteroglot yapısına da değinecek olursak; Huxley'nin romanında karakterleri aracılığıyla farklı sosyal katmanların dillerini, farklı konuşma şekillerini ustalıkla yansıttığını söyleyebiliriz. Romanın bu yönünü ele almak için romanın yazıldığı orijinal dil olan İngilizceden yola çıkmanın daha doğru olacağının bilincindeyiz. Fakat çalışmanın yapısını değiştirmemesi açısından örneklerimizi eserin yine Türkçe çevirisinden vereceğiz ve çok gerekli gördüğümüz yerde İngilizce ifade ve cümleleri de aktaracağız. Ayrıca Huxley'nin okura romandaki çok dillilik/çok söylemlilik konusundaki yardımını da göz ardı etmeyeceğiz. Ses Sese Karş/nın çok dilli söylemine örnek olarak seçilen kısımlar aşağıda sıralanmaktadır: Romanın III. Bölümü'nde anlatııı Illidge'in konuşma şekli için şöyle der: "Illidge, Evet dercesine başını salladı. Eski ve pahalı okullarda elde edilmediği besbelli olan bir şiveyle, "kusursuz," dedi. Lancashire'den geldiği dilinden seziliyordu" (Huxley, 1992, s. 57). Romanın başka bir sahnesinde anlatıcı Kanada asıllı Lady Edward'ın "kalın, güzel bir sesi" olduğunu ve "her söylediği çok ağırbaşlı ve önemli bir sözmüş gibi yavaş yavaş" konuştuğunu belirtmektedir (Huxley, 1992, s. 66). Bunu bir anlamda Lady'nin kendisinin ve mensup olduğu sınıfın önemini belirtircesine konuştuğu şeklinde yorumlayabiliriz. Anlatıcı Lady Edward'ın konuşmasını şöyle betimlemektedir:

İngilizcesi, Fransız asıllı Kanadalıların o hoş şivesine böylesine benzememişti hiçbir zaman. (Çünkü Lady Edward, şivesini istediği gibi değiştirebilirdi. İşine gelince, Kuzey Amerika bozkırlarının saf yürekli bir çocuğu gibi sömürge şivesiyle; işine gelince de, soylu bir İngiliz gibi konuşurdu) (Huxley, 1992, s. 67).

Romanın bir sonraki sayfasında ise Lady'nin partide kendisi ile konuşmaya isteksiz olan Everard Webley ile konuşmasını anlatıcı şöyle aktarır: "Webley!" dedi gene. "Dur! Çüş̧" Lady Edward, köylü arabacının sesini, öylesine bağıra bağıra, öylesine gerçek bir köylü şivesiyle taklit etmişti ki, Webley, konuklar duyarlar da alay ederler korkusuyla, durup dinlemek zorunda kalmıştı" (Huxley, 1992, s. 70). Burada Huxley, İngilizceyi okura, eğitim seviyesi düşük insanlarca konuşulduğu haliyle duyurmaktadır. Konuşmasında değişik şivelerin duyulduğu 
Lady Edward'ın bir başka konuşmasında "r" sesini çok baskılı olarak çıkardığı belirtilmektedir: "Bunları söylerken," $\mathrm{R}$ " harfleri, arslanların kükremesi gibi çıkıyordu Lady Edward'ın ağzından" (Huxley, 1992, s. 73). Belli ki Lady İngilizceyi Kanada aksanıyla konuşan birisidir. Böylelikle Huxley, Lady Edward'ın konuşma biçiminde İngilizcenin farklı bir şivesini yansıtmaktadır. Roman yazarı Philip Quarles'ın toplum içinde kendini yabancı hissettiğini, sosyal bir insan olmadığını ve başkalarıyla iletişim kurmasında eşi Elinor'un ona destek olduğunu, neredeyse diğer insanların konuşmalarını Philip'e tercüme ettiğini biliyoruz (Huxley, 1992, s. 130). Çünkü Philip aslında kendisini yaşadığı topluma yabancılaştıran ve "anadili olan ve düşünceye dayanan aydın dilini" konuşmaktadır (Huxley, 1992, s. 127). Huxley doğal olarak Philip'in roman boyunca her konuşmasında, her sözcüğünde entelektüel kesimin konuştuğu dili kullanmasını sağlamıştır. Roman boyunca aydın dilinin, buna anlatıının kendi dili de dâhil olmak üzere, yer yer Fransızca, Latince, İtalyanca ve Almanca dillerinden alınan kelimeler, ifadeler ve cümleler ile süslendiği ve çeşitlendirildiği de görülmektedir. Örneğin, Walter'ın Lucy'e umutsuzca tutkusu, Walter'ın aklından geçen Latince bir ifade ile verilmektedir: "Credo quia absurdum Amo quia turpe, quia indignum... [...] Saçma olduğu için inanıyorum. Kötü olduğu için, beni küçük düşürdüğü için seviyorum" (Huxley, 1992, s. 94). Spandrell yaşamından memnun olmayan veya oyuncu olmak isteyen tuzağına düşürdüğü genç kızları "âmes incomprises" yani "anlaşılmayan ruhlar" (Huxley, 1992, s. 188) olarak tanımlar. Philip'in gemi yolculuğu sırasında güvertede duyduğu kadınların İngilizce-Fransızca karışık konuşmaları ve Philip'in de bu konuşmaları romanının çok sesli doğasını yaratmak için tekrar etmesi onun dilinin Fransızca yankılar içermesine örnek teşkil etmektedir (Huxley, 1992, ss. $307,308)$. Romanın başka bir sahnesinde ise işsiz güçsüz, annesinden aldığı parayla yaşayan Spandrell'ın saçma sapan bir düşünce olarak gördüğü, çalışmanın kutsallı̆ı düşüncesinin Latince terimlerle aklına geldiği görülmektedir: "labotare est orare" (Huxley, 1992, s. 346). Everard Webley'nin Elinor'a ve Lucy'nin de Walter'a yazdığı mektuplarda görülmektedir ki her iki roman kişisinin de dilleri yabancı dillerden etkilenmiş ve dolayısıyla kullandıkları dil kendilerine özgü ve kendi kültürel durumlarını yansıtır bir hale gelmiştir. Webley "Sevgli Elinor" diye başladığı mektubuna Latince olarak "De Profundis Clamav" yani "Uçurumun derinliklerinden sesleniyorum" (Huxley, 1992, s. 478) diye devam eder. Lucy'nin Paris'teyken Walter'a yazdığı mektup bir dizi Fransızca, İtalyanca ve Almanca ifadeler içermektedir. Örneğin; Paris'te iyi vakit geçirdiğini "Quant a moi, je m'amuse. Pas follement" yani "Bana gelince, eğleniyorum. Deliler gibi değil" (Huxley, 1992, s. 503) şeklinde ifade etmektedir. "Cinsel sapıkların ne erkeklerinden, ne de kadınlarından hoşlanıyorum" derken İngilizce-Fransızca karışık bir ifade şeklini tercih etmektedir: "Niles tapettes ni les goussese'lardan hoşlanıyorum aslında" (Huxley, 1992, s. 504). Yine aynı mektupta İtalyanca olarak "Cuore - dolore - amore" yani "Yürek, acl, aşk" der ve bu terimleri İngilizce cümle içinde bir de Almanca olarak kullanır: "[H]erz must feel schmerz and liebe is inevitably full of triebe" (Huxley, 2008: 215). Yani, "Herzin schmerz duyması gerek ve liebe'nin de triebe ile dolu olmasının önüne geçilemez" (Huxley, 1992, s. 504) der. Burada 'herz', 'yürek'; 'schmerz', 'acı'; 'liebe' 'aşk' ve 'triebe' ise '(bir şeyi harekete geçiren) duygu/uyaran' demektir. Bu mektubun 
kalan kısmı ile Walter'a başka bir zaman yazdığı mektup da zaman zaman bu şekilde, bahsedilen dillerden terimler içermektedir (Huxley, 1992, ss. 505-507, 572-573). Anlatıcı Rampionların zenginler gibi yaşamaya yetecek kadar para kazansalar bile tek bir hizmetçileri olduğunu, evişlerinin çoğunu kendilerinin yaptığını çünkü "yoksullar gibi" yaşamanın Mark Rampion için "ahlak açısından bir çeşit zorunluluk" olduğunu Mark'ın kendi konuşmasında olduğu gibi Fransızca terimlerle ifade eder: "Rampion için bir noblesse oblige, daha doğrusu bir roture oblige sorunuydu bu." Burada italik yazılan ilk ifade "soylu olan kişi soyluca davranmalıdır", ikincisi ise " aşağı sınıflardan gelen kişi, kendi sınıfına uygun bir biçimde davranmalıdır" anlamındadır (Huxley, 1992, s. 183). Yukarıda sayılan örneklerde görüldüğü üzere roman kişilerinin konuşmalarında yabancı dillerin etkilerinin görülmesi, dillerinde yabancı dillerden alınan kelime veya ifadelerin olması bu roman kişilerinin bir şekilde bu yabancı diller ile haşır neşir olduklarını göstermektedir. Bu durum aslında dilbilimde 'code-switching' olarak bilinen ve çeşitli nedenlerle ortaya çıkan ve bir dilden diğerine bir ek, kelime, ifade veya cümleyi ödünç alma biçiminde görülen bir dil kullanımıdır. Burada bir roman kişisinin dilinde görülen başka bir dilden yapılan ödünç almalar daha çok onun sosyal statüsünü anlamamıza yardımcı olmaktadır. Karakterlerin bu tür konuşma şekilleri aldıkları eğitimi göstermenin yanı sıra kültürel birikimlerini de açığa vurmaktadır. Yukarıda örneklendiği gibi, roman kişilerinin 'code-switching' yaparak konuşması veya yazması (her ne kadar code-switching' konuşmayla ilgili bir dil kullanımı olsa da) karakterlerin bunu kendilerinin belli bir sınıfa ait olduğunu, entelektüel veya elit tabakanın birer üyesi olduklarını vurgulamak amacıyla veya spontane olarak yaptıkları fikrine götürebilir. Nedeni ne olursa olsun karakterlerin dili kullanma şekillerinin, dilin sosyal katmanlarca farkı biçimlerde kullanılmasının bir sonucu olduğu görüşüne varabilir ve onların dili kullanma biçimini dilin heteroglot yapısı ile ilişkilendirebiliriz. Ses Sese Karş/da dilin değişik kullanımlarını göstermeye devam edersek; Lucy ve zenginlerin sıkça gittiği Sbisa Lokantasının sahibi yaşlı Sbisa'nın "Napoli'lilere özgü ve genellikle Doğululara özgü bir biçimde sözcüklere basa basa" konuştuğu, Lucy ve Walter'ı kapıda bozuk şivesiyle sürekli konuşarak karşıladığı söylenmektedir (Huxley, 1992, s. 152). Bu oryantal şive İngilizce konuşmada daha net olarak duyulmaktadır: "Oo yez, oo yez [...] And you? Quaite well, quaite well, I hope? Sooch lobster we have to-night, sooch lobster..." (Huxley, 2008, s. 64) Mr. Sita Ram de aynı şekilde İngilizceyi fonetiğine uygun olmayan bir şekilde konuşmaktadır. Bu da doğal olarak onun ana dilinin Hintçe olmasından ve İngilizceyi yabancı dil olarak öğrenmesinden ileri gelmektedir. Burada örnekleri romanın yazıldığı dil olan İngilizceden vermekte fayda var. Örneğin, 'the' yerine "de", 'think' yerine "tink" demektedir. "I was re-reading some of de works of Morley to-day", "What a tinker!", "dere are some good phrases", "I wrote dem down" (Huxley, 2008, s. 48) gibi ifadelerde görüldüğü üzere Mr. Sita Ram fonetik açısından bozuk bir şekilde konuşmaktadır. Okura, Burlap'ın, konuşmalarında yer yer halkın kullandığı resmi olmayan dile ait ifadeler serpiştirdiği ve argo sözler kullandığı bilgisi verilmektedir; bunu Mark Rampion şöyle betimlemektedir: "Burlap, argo deyimleri, İngilizceyi kusursuz konuşan, ama yabancı olduğu gene de anlaşılan biri gibi kullanıyor. [...] "Bir Hintlinin 
'yaman bir adamdır' dediğini bilmem hiç duydunuz mu? İşte, bunu anımsatıyor bana Burlap'ın argo deyimleri" (Huxley, 1992, s. 207). Bayan Bidlake'in küçük pekin köpeğinin adını söylerken "T'ang" kelimesindeki kesme işaretini belirtmesi, kültürlü ve İngilizceyi fonetik açısından doğru konuşan insanların yaptığı gibidir. Anlatıcı bize Mrs. Bidlake'in bunu "kültürlü bir insanın içgüdüsüyle, farkına varmadan" belirttiğini söyler (Huxley, 1992, s. 298). Sidney Quarles'ın aşağı sınıftan ve yoksul metresi Gladys'in bazen bu halini yansıtırcasına bir konuşma tarzı olduğunu gösteren ifadeler kullanılmıştır. Örneğin, "yapma be!", "eyvallah" (Huxley, 1992, ss. 426-427) gibi ifadeler kullanır. Bunun nedenini ise anlatıcı şöyle açıklar: "Gerçi Gladys kibar konuşurdu ama; dilini örten bu yapay kibarlık, zaman zaman üstünden sıyrılıverir; Londra'nın aşağı tabakalarına özgü sözcükler, tümceler, olanca çırılçıplaklı̆ııla ortaya çıkıverirdi" (Huxley, 1992, s. 426). Huxley'nin avukatlara özgü dili mektup aracılığıyla da olsa yansıtması dilin heteroglot özelliğinin romandaki bir başka yansımasıdır. Yaşlı Sidney Quarles'dan hamile kalan Gladys'i başlarından savmak için Philip'in tuttuğu avukat arkadaşı Willie Weaver'ın Philip'e yazdığı mektup tamamıyla resmi bir dille yazılmış olup avukatlara özgü terim ve ifadeler içermektedir (Huxley, 1992, ss. 667-668; Huxley, 2008, s. 285). Jargon denilen ve dilin belli meslek gruplarınca kullanılan şeklini romanda ayrıca doktorların kendi aralarında kullandığı dil aracılıyla da duymaktayız. Sir Herbert ile diğer doktorun, John Bidlake'in midesinin röntgen filmi üzerine konuşmaları doktor jargonu içermektedir (Huxley, 1992, s. 497). Romanda görülen farklı dil katmanlarına verilebilecek başka bir örnek ise küçük Phil'in dilidir. Phil çim biçme makinesine "biçen-çimen" (Huxley, 1992, s. 300) demekte, büyüklerin konuşmasını "seni gidi yaramaz!" (Huxley, 1992:393) diye taklit etmekte ve babasına öfkelendiğinde "papağanlar gibi, sinir bozarcasına "Yaramaz baba!" sözünü yinelemektedir (Huxley, 1992, s. 496). Romanın bir başka sahnesinde ise Mr. Quarles'ın kendini beğenmiş tavırlarına eşlik eden abartıı bir İngilizce ile konuştuğu belirtilmektedir. Anlatıcı şöyle betimler Yaşı̆ı Quarles'ın konuşmasını: "Oxford'da okuyanların, İngilizceyi zenginleştirmek amacıyla bu dile ekledikleri melemelerle doluydu çın çın öten sesi. "Really" sözcüğü, Sidney'in ağzında "ryahly" biçimini, "mere" sözcüğü "myah" biçimini alırdı." Sidney Quarles'ın ağzından çıkan sözlerin arasına, bir koyun sürüsü dalmıştı sanki" (Huxley, 1992, ss. 406-407). Aynı şeyi İngilizcedeki 'figure', 'dear', 'hear've 'unnecessary' gibi kelimelerde de yapmaktadır: bu kelimeleri "figah" , "dyah" (Huxley, 2008, s. 182), "hyah" (Huxley, 2008, s. 183) ve "unnecessarah" (Huxley, 2008, s. 247) şeklinde söylemektedir. Belli ki yazar burada yüksek sınıftan gelen ve Oxford'da okuyan bazı İngilizlerin abartılı şivesiyle alay etmektedir. Ses Sese Karş/da dilin çok katmanlı kullanımına verilebilecek son bir örnek de Britanyalı Hür Adamlar'ın kurucusu Everard Webley'nin söylevidir. Webley, "Britanyalı Hür Adamlar! Arkadaşlarım!" diye seslenmeyle başladığı konuşmasına coşkulu bir şekilde devam eder. Burada Webley'nin söylevini olduğu gibi vermek yerine söylevin bir politikacının konuşmasında yer alabilecek olan 'özgürlük', 'fethetmek', 'görev', 'ülke', 'kurtarmak', 'savaş', 'ordu' ve 'demokrasi' (Huxley, 1992, ss. 538-539) gibi kelimeler içerdiğini söylemekle yetineceğiz. Görüldüğü üzere, Ses Sese Karşı dilin 
değişik sosyal ve kültürel tabakalarına ait kullanımları barındıran heteroglot yapısıyla polifoni özelliğini daha da pekiştirmektedir.

\section{Sonuç}

Huxley'nin Ses Sese Karşı adlı romanının polifonik yapısını inceleyen bu çalışmanın sonucunda görülüyor ki, romana bu özelliği kazandıran temel öğe, yazarın modern dünyanın kavram ve olgularından kaynaklanan düşünce, kanı, görüş ve anlayış çeşitliliği sunan, ve bir anlamda, birbirinden bir hayli farklı düşüncelerin kişiliklerinde somutlaştırıldığı on dokuz roman kişisinin her birini özerk ve bağımsız sesler olarak okura duyurmasıdır. Yazar romanını bu değişik kanı ve görüşleri aynı çoksesli müzikte olduğu gibi kontrpuntal bir biçimde yan yana dizerek, bunları eşsesli olarak, her bir sesin eşit biçimde duyulabildiği ve bir sesin diğerine göre üstün olmayacağı bir şekilde yapılandırmıştır. Roman kişilerinin farklı bakış açıları ve seslerinin yanı sıra yazar-anlatıcının bakış açısı ve sesi de romanda duyulan başka bir bağımsız ses durumundadır. Romanın polifonisini ortaya çıkaran düzlem ise onun diyalojizmidir. O nedenle çalışmada Ses Sese Karş/nın diyalojik özellikleri incelenmiş ve anlamın diyalojik düzlemde ortaya çıktığı, karakterlerin sözlerinin birbirini açımladığı ve karakterlerin birbirleri, kendileri ve yaşam ile içinde yaşadıkları dünya hakkındaki her şeyin bu düzlemde açığa çıktığı ortaya konulmuştur. Diyaloglarda olduğu gibi içsel seslerin duyulduğu monologlarda bile bir karakterin diyalogunun tınılarının diğerinin diyalogunda duyulduğu romandan örneklerle saptanmıştır. Aynı zamanda karakterlerin bilinçlerinin birbirlerinde yansıdığı, birbirleri hakkında birçok şey bildikleri ve bunları hesaba katarak seslerini duyurdukları; ayrıca her karakterin bir öz-bilinci olduğu ve dolayısıyla kendileri hakkında daima söyleyecek sözleri olduğu gözlenmiştir. Bu özellikler de diğerleri gibi polifonik bir romanın ayırıcı özellikleri olup, karakterler ve onların bakış açıları, düşünceleri, kanıları vs. hakkında son sözü söyleyen, onları nesnelleştiren ve nihaileştiren yazarın ya da anlatıcının yazarsal/otoriter bakış açısını sarsmaktadır. Polifonik bir romanın önemli bir özelliği daha olan romanın heteroglot özellikleri de çalışmada yer almaktadır. Ses Sese Karş/nın, dilin sosyo-kültürel özelliklerinden doğmuş olan aynı dil içinde farklı diyalekt ve konuşma biçimleri içerdiği, bu yüzden de heteroglot bir yapısı, yani çok dilli, çok söylemli bir yapısı olduğu sonucuna varılmıştır. Ses Sese Karşı tüm bu özellikleriyle tam bir modernist roman olup, okura tek ve sabit bir anlam sunan monolojik romanların tersine bir anlam çokluğu sunmaktadır. Huxley'nin romanına koyduğu tüm olumsuzluklar romanın bir umutsuzluk havası içinde bitmesine neden olmakta ve yaşamın kestirilemez olduğunu, boşluğunu ve anlamsızlığını açığa vurmaktadır. Romanın sonunda durumundan hoşnut karakterler olarak sadece Denis Burlap ve Beatrice görülmektedir. Roman boyunca Burlap sürekli olarak parasızlıktan şikâyet eden aslında diğer insanları sömüren iğrenç bir adam olarak, Beatrice ise cinsel anlamda soğuk, yaşı geçkin bir kız olarak gösterilmiştir. Romanın, Burlap ve onun baştan çıkardığı Beatrice ile banyoda gülüşmeleri, etrafa su sıçratarak oynamalarının görüldüğü son sahnesi ise geleneksel roman okuyucusunun alışık olmadığı türde bir sondur; çünkü bu son romanda görülen olayları çözüme 
ulaştırmaktan ve okuyucuya tek kesin bir anlam sunmaktan bir hayli uzaktır. Aslında romanın okuru karakterlerin ya çözümlenmemiş ya da umut vaat etmeyen öyküleriyle baş başa bırakması ve çözüm sunmayan bir son sahne içermesi onun polifonik bir roman olma özelliğini pekiştirmektedir. Polifonik roman karakterlerini yazar hiçbir zaman nihaileştiremez yani onları tamamıyla anlaşılır ve bilinebilir kılamaz, onları etiketleyemez; onlar hakkında son sözü söyleyemez. Tam da bu özellik Ses Sese Karş/yı monolojik bir romandan ayıran özelliklerden biri olarak karşımıza çıkmaktadır. Ses Sese Karş/da yaşamların çeşitliliğini ve insan deneyimlerinin karmaşıklığını sergileyen bir polifoni vardır. Tüm sesler aslında kanılar ve dünyaya bakış açılarıır. Sesler ve tınılar eşzamanlı olarak, müzikte olduğu gibi kontrpuntal bir tarzda yan yana konmuşlardır. Roman bu haliyle çok sesli bir gerçeklik sunmaktadır: Gerçeklik tek bir aklın, zihnin ürünü olamaz; tek bir sesin ifadesi olamaz; aslında zaten ifade edilecek tek ve sabit bir gerçeklik de yoktur. Huxley'nin romanının bütünselliği çok sesli romanların bütünsellik sorununu elbette taşımaktadır. Romandaki bütünsellikten bahsedilecekse bu bütünsellik romanın biçimsel bütünlüğüne işaret edecektir. Romanın dışsal tamamlanmışlı̆ı ile içsel açık-uçluluğu arasında polifonik romanların değişmez bir karakteristiği olarak görülen çelişki Ses Sese Karş/da da ayırıcı bir özelliktir. Roman bittiğinde dahi karakterler hâlâ tartışmaya devam ediyormuş izlenimi verilir. Romanın açık-uçluluğu ve tamamlanmamışlı̆ından dolayı tamamen çoksesli bir sonu vardır. Okuyucunun romandan aldığı şey yazarın tek, kesin, değişmez bir gerçeklik olarak sunduğu görüş değil, gerçekliğin her bir karaktere nasıl göründüğüdür. Her ne kadar monolojik bir yaklaşım gibi gözükse de, romanda tematik anlamda bir bütünlük arayışına girdiğimizde elde ettiğimiz şeyin yine romanın polifonik yapısıyla ilgili olması kaçınılmazdır: Ses Sese Karşı' da deneyimlediğimiz haliyle dünya çoksesli, değişik sesli, çok merkezli ve anlamlar çokluğu barındıran bir yerdir.

\section{Kaynakça}

Abrams, M.H., (1999). A glossary of literary terms. (7. Bs.). Amerika: Heinle \& Heinle. Allen, Graham, (2000). Intertextuality. (Routledge. Taylor \& Francis Group.

Bakhtin, M. M. (2004). Dostoyevski poetikasının sorunları. Cem Soydemir (Çev.) İstanbul: Metis.

Bakhtin, Mikhail M. (1999). Problems of Dostoevsky's Poetics.Carly Emerson ve Wayne C. Booth (Ed. Ve Çev.). Minneapolis: University of Minnesota Press.

Bakhtin, Mikhail M. (1986). Speech genres and other late essays. Austin: University of Texas Press.

Bakhtin, Mikhail M. (1981). Michael Holquist (Ed.), Carly Emerson ve Michael Holquist (Çev.), The dialogic imagination: Four essays. Austin: University of Texas Press.

Booth, Wayne C. (2004). "Sunuş". Cem Soydemir (Çev.), Dostoyevski poetikasının sorunları içinde (ss. 7-24). İstanbul: Metis.

Burgess, Anthony. (1974). English literature. (9. Bs.). İngiltere: Longman Group Ltd.

Clark, Katerina, ve Michael Holquist, (1984). Michael bakhtin. Amerika: Harvard University Press. 
Dentith, Simon. (1996). Bakhtinian thought: An introductory reader. Büyük Britanya: Clays Ltd.

Huxley, Aldous. (1931). Tragedy and the whole truth. The virginia quarterly review. 176185.

Huxley, Aldous. (2008). Point Counter Point. London: Routledge-Curzon

Huxley, Aldous. (1992). Ses Sese Karşı. (3. Bs.) Mina Urgan (Çev.), İstanbul: İletişim Yayınları.

Kettle, Arnold. (1969). An introduction to the english novel: Volume II Henry james to the present day. Londra: Hutchinson University Library.

Lodge, David, (1990). After bakhtin: Essays on fiction and criticism. Londra ve New York: Routledge.

Lodge, David, ve Nigel Wood. (Ed.). (2000). Modern criticism and theory: A reader. Singapur: Longman Ltd.

Marovitz, Sanford E. (1969). "Aldous huxley's intellectual zoo", Philological quarterly, 48: 495-507.

Meckier, Jerome. (1969). Aldous huxley: Satire and structure. London: Chatto and Windus.

Meckier, Jerome. (2010). "Quarles among the monkeys: Huxley's zoological novels", Harold Bloom (ed.). Bloom's modern critical views: Aldous huxley içinde (ss. 5976). New York: Infobase Publishing.

Smith, Grover (Ed.). (1969). Letters of aldous huxley. Londra: Chatto \&Windus.

Strauch, Eduard Hugo. (2001). Beyond literary theory: Literature as a search for the meaning of human destiny. Amerika: University Press of America, Inc.

Quina, James. (1977). The mathematical-physical universe a basis for multiplicity and the quest for unity in Point Counter Point. Studies in the Novel, 9, 4: 428-444. Amerika: University of North Texas.

Urgan, Mina. (1992). "Önsöz". Ses Sese Karşı içinde (ss. 5-12) Mina Urgan, (Çev.). İstanbul: İletişim Yayınları

Voloshinov, V. N. (1973). Marxism and the philosophy of language. Ladislaw Matejka ve I. R. Titunik (Çev.) New York ve Londra: Seminar Press, Inc.

Woolf, Virginia. (1986). "Modern Fiction". The Norton Anthology of English Literature. (5. Bs.). M. H. Abrams vd. (Ed.) içinde (ss.1993-1999). New York ve Londra: W. W. Norton and Company, Inc.

\section{Elektronik Kaynaklar}

Huxley, Aldous, The Herman Harvey Interview, hhtp://www.youtube.com/watch?v:clhqajR qgA (2013Eylül 9)

Marovitz, Sanford E. (2013), "Point Counter Point. Huxley's tragi-comic performance of the "human fugue", http://www.dalkeyarchive.com/wpcontent/uploads

Lpdf/Huxley Point Casebook/marovitz.pdf (2013 Ekim 1) 